\title{
GOVERNING SGIENGE: PUBLIC RISKS AND PRIVATE REMEDIES
}

\section{BARRY R. FurRow†}

Scientific progress has brought innumerable benefits: new sources of energy, more effective medical care, and most important, a greater understanding of ourselves and our physical environment. Simultaneously, however, science has created hazards both as a by-product of ongoing research in fields such as biology and as a result of technologies developed out of scientific research. Contemporary scientific research increasingly presents hazards of uncertain probability and magnitude. These hazards often fall in the gray areas outside of the jurisdiction of existing government agencies. The nature of the hazards is not recognized initially except by those directly engaged in the research, and the lack of controls enables a technology to develop before a preliminary assessment can take place. The ideology of modern science combines with these institutional deficiencies to create a need for more effective controls over scientific research.

This article contends that private, rather than public, action can deal effectively with scientific risks. Private tort litigation can play an important role as a risk-assessment mechanism in the development of new technologies if the content of common law entitlements is redefined and coupled with expanded judicial powers. Common law rules of entitlement, expressed in nuisance law, parallel contemporary perceptions of scientific and technological hazards, as reflected in much recent federal legislation. ${ }^{1}$ In a regulatory vacuum, private law offers the only avenue for regulating certain categories of risks produced by scientific research. The thesis of this article has three parts: a substantive theory of entitlements, a procedural model, and an analysis of the social con-

$†$ Associate Professor of Law (Visiting), University of Detroit; Lecturer, Dep't of Environment and Industrial Health, School of Public Health, University of Michigan. A.B. 1967, J.D. 1971, Harvard University.

I am grateful for the financial support I received from the University of Michigan Law School as a visiting professor in 1981-82, and from the Washington College of Law, American University, where I first began to think about the problems of technology assessment. I am particularly indebted to Susan Wright, of the Residential College of the University of Michigan, for her constructive comments.

1 See, e.g., Clean Air Act, 42 U.S.C. \$\$ 7401-7642 (Supp. I 1977); Water Pollution Control Act, 33 U.S.C. § 1251 (1976); Safe Drinking Water Act, 42 U.S.C. § $300 \mathrm{~g}-l$ (1976); Federal Insecticide, Fungicide and Rodenticide Act, 7 U.S.C. $\S 136$ (1982); Occupational Safety and Health Act, 29 U.S.C. $\$ \S 651-678$ (1976). 
text of the risks of scientific research. The theory of entitlements derives from well established tort concepts of nuisance law; the procedural model acknowledges and draws upon the burgeoning powers of the judiciary as demonstrated in contexts such as the structural reform of prisons and other public institutions; and the social analysis evaluates the newly created risks-of unknown probability and high consequence-generated by modern research.

New risks are generated daily in our industrialized, technological society: risks associated with toxic substances in the chemical industry, side-effects of drugs, and unforeseen effects of apparently benign technologies such as aerosol can propellants. The concept of risk has itself been expanded by modern science and medicine to include previously unsuspected categories of hazards such as carcinogenesis (induction of runaway growth of the cells of some part of the body), mutagenesis (modification of the body's genetic material), and teratogenesis (alteration of the development of a fetus in utero). ${ }^{2}$

Risks generated by research activities are in a special category. Unlike the usual environmental harms, where the damage-creating instrumentality is already producing a by-product that poses some level of long term health impact, harms associated with genetic research, for example, include problems of feared catastrophe, with uncertainty as the dominant feature. The problem of uncertainty is intensified because of the possibility that research into fundamental biological or physical structures may alter those structures in a way that does not normally occur in the natural environment. How then is this problem different from industrial production of toxic chemicals or radioactive by-products and airborne or waterborne effluent which may have long-term health effects? The uncertainty of harm may be just as pronounced. Radioactive materials pose unique half-life problems, requiring in some cases thousands of years to decay to a nonthreatening level. Certain toxic chemicals likewise may not degrade, or may break down in pernicious and unpredictable ways. Both radioactive materials and toxic chemicals may enter the food chain or ecological niches in ways which pose longterm threats. With either type of hazard, however, the risk is enhanced because of the sheer volume of the hazardous substances produced as by-products of large-scale commercial use and production. Production and use can therefore be reduced, stopped, or altered; the source of the hazard, being traceable, can be pinpointed, and most important, regula-

2 For a general discussion, see W. Lowrance, Of Acceptable Risk: Science and THe Determination of Safety 24-29 (1976); MANagement of Assessed RISK FOR CARcinogens (W. Nicholson ed. 1981); Ames, Identifying Environmental Chemicals Causing Mutations and Cancer, 204 ScI. 587 (1979). 
tory measures to govern production, shipment, and storage can be implemented by existing government agencies.

Research, such as the biological research that gave rise to the recombinant DNA controversy, offers hazards of a different order of magnitude. The putative risks involve pathogens, altered organisms, and changed immunological defenses. Harmful organisms can reproduce and mutate if an adaptive niche is available. The level of production required for self-sustaining growth may require only a single laboratory experiment, in contrast with toxic chemical by-products linked to commercial levels of production. Attention to research hazards is therefore best directed to the earliest stages of investigation.

Science is as yet unregulated in any meaningful way by a government agency with a specific mandate to protect a client group from hazards. Agencies which fund research, such as the National Science Foundation and the National Institutes of Health (NIH), exist to orient research in the most promising directions and to fund the best of that research. ${ }^{3}$ These relationships are quite unlike the relationship of the Food and Drug Administration (FDA) to the pharmaceutical industry, the Occupational Safety and Health Administration (OSHA) to workers in industry, and the Consumer Product Safety Commission (CPSC) to manufacturers of consumer goods. In light of scientific selfregulation, this vacuum is viewed as harmless by some. Given the limits of self-regulation, however, and the peculiar uncertainties attendant upon research, a regulatory vacuum is undesirable. Some systematic means of evaluating risks is necessary.

The goal of any institution which would focus on the hazards of scientific research would not be to reach scientific truth, nor to resolve a controversy within a field, but rather to get some sense of the nature and probability of the risks, to inform the relevant affected public of the nature of the activity, and to send a message to government decisionmakers. In the area of new hazards, "an explicitly intrusive approach is required, one that judicial scrutiny can provide."

3 The mandate of the National Science Foundation is "to initiate and support basic scientific research and programs and to strengthen scientific research . . . and to appraise the impact of research upon industrial development and upon the general welfare." Nat'l Sci. Found. Act, 42 U.S.C. § 1862(a)(1) (1976).

4 Yellin, High Technology and the Courts: Nuclear Power and the Need for Institutional Reform, 94 HARv. L. REv. 489, 541 (1981) (recommending a more intrusive approach to judicial review of agency decisionmaking). For an interesting analysis of various opposition movements in America to technologies such as the fluoridation of water, see Mazur, Opposition to Technological Innovation, 13 MINERva 58, 81 (1975). For an expanded discussion by Mazur of the fluoridation controversy and other technological issues, see A. Mazur, The Dynamics of Technical Controversy (1982). 
The recombinant DNA controversy offers an excellent case study for assessing the problems of regulating scientific research. Recombinant DNA research and the bio-technology that has emerged from it command our attention because of scientific perceptions of the promise of the technique in uncovering areas of ignorance about human genetic structure, and the promise of profitable commercial applications. ${ }^{6}$ It is a paradigm case, like the development of nuclear research in the 1950's, for hazards inherent in the research itself, raising questions about the technique, its directions, and the effectiveness of scientific self-regulation when confronted with risky research. ${ }^{6}$ Scientific progress and commercial promise have fueled a shortened interval between the initial stages of an area of research and its first technological applications. The recombinant DNA controversy highlights the troubling issues in regulating research. How do we uncover risks early? By what mechanisms? What mix of public regulation and private law can fill the void now surrounding the hazards of scientific research? A judicial "first look" doctrine can enhance the process of discovering and analyzing

- Commercial applications of the recombinant DNA technology have burgeoned; investors have seized upon it as the new technology of the eighties, replacing microprocessing as the leading scientific investment opportunity. See Drinkhall, ExConvict and Microbiologists Join Forces to Ride the Genetic-Engineering Wave, Wall St. J., Mar. 4, 1981, at 31, col. 4; Shaping Life In the Lab, TiME, Mar. 9, 1981, at 50. Larger established chemical and drug companies have either expanded their existing research or have worked out collaborative arrangements with the new companies created to market the products of recombinant DNA technology. See Genentech Reports Output of Hornone To Spur Cow Growth, Wall St. J., Mar. 16, 1981, at 32, col. 2. It has been described as "one of the biggest industrial opportunities of the late 20th century." Shaping Life In the Lab, supra, at 51. See generally Elia, Commercial Potential of Genetic Engineering Seems to Be Vast in Coming Decade, Study Says, Wall St. J., Jan. 16, 1981, at 37, col. 3. Humulin, a synthetic form of insulin, became the first drug made from synthetic genetic materials approved for human use by the U.S. Food and Drug Administration. As of November, 1982, Humulin, the first such insulin drug, was made with a synthetic duplicate of human genes, and licensed by Genentech to Eli Lilly \& Co. for production and sale as a nonprescription drug. Artificial Genes: Biotech Comes to the Drugstore, TIME, Nov. 15, 1982, at 65.

- It has been seen by scholars of science and society as "a metaphor grown large for the general problem of controlling the dangerous products and processes which are the fruits of modern science." M. Shapo, A NAtion of Guinea PIgs 226 (1979). See also Subcommitree on Science, Research, and Technology of the House Committee on Science and Technology, 96th Cong., 2d Sess. Genetic Engineering, Human Genetics, and Gell Biology: Evolution of Techinological Issues, BIotechnology (Comm. Print 1980); Green, The recombinant DNA controversy: a model of public influence, 34 Bull. Atom. Scientists 12 (1978). But see Graham, Concerns about Science and Attempts to Regulate Inquiry, 107 DaEDALus 1, 13 (1978).

This article focuses on public health risks, broadly defined. The risks of abuse, such as the use of genetic engineering techniques for biological warfare, are not discussed. Such concerns are important, but not easily subject to the control mechanisms I propose. For a discussion of such potential misuses, see Wright \& Sinsheimer, Recombinant DNA and Biological Warfare, 39 Bull. Atom. Scientists 20 (1983). 
new hazards in an era of overworked, understaffed, and beleagured federal agencies. ${ }^{7}$

\section{The Problem of Regulating Scientific Research}

\section{A. The Paradigm Case: The Recombinant DNA Controversy}

The controversy over genetic research provides a useful case study of the problems of regulating science, ${ }^{8}$ offering arguments for and against regulation, diverging viewpoints on risk assessment, and a clarification of values. The discoveries of molecular biology, like the revolution in quantum physics, have transformed our understanding of the natural world, allowing scientists to manipulate the genetic code, and raising hopes that the structure and function of genes in higher organisms can be understood. ${ }^{9}$ Recombinant DNA (rDNA) research in particular, as part of the revolution in biology, has offered a technology for producing hormones, antibodies, interferon, antigens in immunization, and an efficient means of introducing nitrogen fixation ${ }^{10}$ in higher plants. The benefits, both purely scientific and practical, stand in sharp contrast to the perceived hazards of the research.

The hazards of rDNA research are an integral part of the technique used. The genetic code that determines the properties of living organisms is contained in a long helical molecule found in every living cell. ${ }^{11}$ Biologists have learned how to divide that molecule into segments, attach segments of one molecule to another, and reimplant this restructured molecule in a living cell. As a result, one or more of the properties of the cell from which the new fragment was taken will be imparted to the host cell. The host cell, commonly Escherichia (E.) Coli

7 For a critical view of creating new regulatory agencies in response to perceived national problems see J. Dunlop, The Limits of Legal Compulsion (Nov. 12, 1975) (unpublished manuscript) (on file with University of Pennsylvania Law Review).

- See Note, Recombinant DNA and Technology Assessment, 11 GA. L. REv. 785 (1977) (excellent discussion of alternative regulatory approaches); Comment, Considerations in the Regulation of Biological Research, 126 U. PA. L. Rev. 1420 (1978).

- NIH describes the technique's impact as "a profound and qualitative change in the field of genetics." National Institutes of Health, Final ENvironmental IMPACT Statement on NIH Guidelines FOR Research INVOLVING RecombiNANT DNA Molecules, pt. 1, at v. (1977) (hereinafter cited as Final EIS). For a more recent perspective, see Lewin, Biggest Challenge Since the Double Helix, 212 Scr. 28 (1981).

10 See Abelson, A Revolution in Biology, 209 Scr. 1319 (1980); Davis, Frontiers of the Biological Sciences, 209 Sar. 78 (1980). For an excellent history of the developments in modern molecular biology, see H. Hudson, The EightH DAY OF GREATION (1979).

11 See James Watson's first person account in J. Watson, The Double Helix (1968). For a useful simplified discussion, see R. HUTTON, BIo-Revolution: DNA AND THE ETHICS OF MAN-MAde Life 93-112 (1978). 
bacteria, can replicate itself, including its new genetic code, by division into two cells which can in turn divide and replicate in a process controlled only by available nutrients.

The risks of recombinant DNA research, described by the Supreme Court as "a gruesome parade of horribles,"12 take several forms. ${ }^{13}$ First, the properties of the recombination cannot be known completely, and some of these new properties might be dangerous. In fact, the very purpose of the experiment might be to break down and recombine a complex molecule in order to determine its properties. Second, the host cell for recombinant DNA experiments was one or another strain of $\mathbf{E}$. Coli, strains of which commonly reside in the human intestine. E. Coli was the vehicle of choice because its native properties are thoroughly known, making it easier to identify the properties of a foreign fragment of DNA by observing the changes it produces. ${ }^{14}$ The use of $\mathrm{E}$. Coli as a vehicle for experimentation, however, makes possible the scenario in which an artificially altered host cell could be widely disseminated among humans, plants, and animals. A pathogenic bacterium could thus spread quickly after escaping the laboratory setting by transfering genes to other E. Coli strains. These harmful new strains could prove uncontrollable by normal antibacterial agents. Third, the insertion of DNA derived from a different species may change certain properties of that host. In the words of the NIH Environmental Impact Statement, "[ $t$ ]he change may be advantageous, detrimental, or neutral with regard to (a) the survival of the recipient species, (b) other forms of life that come in contact with the recipient, and (c) aspects of the nonliving environment."15 Fourth, a recombinant form of life might be so foreign that its mere presence in the host system, irrespective of any pathogenic qualities, could be a health hazard. The host system's regu-

12 Diamond v. Chakrabarty, 447 U.S. 303, 316 (1980) (man-made organism is patentable; risks of research for legislature to consider, not the Court).

13 For a general discussion of the risks, see FinAL EIS, supra note 9.

14 The choice of $\mathrm{E}$. Coli as a host for recombinant DNA research is itself a questionable one, but the quantity of information which had accumulated about its characteristics dictated its use in the eyes of the scientists involved. DeWitt Stetten, NIH deputy director for science and chairman of the NIH Recombinant DNA Committee, in a letter of October 6,1975, wrote to a critic:

You are . . . undoubtedly correct [in principle] that $E$. coli is the wrong microorganism. . . . Even at the Asilomar Conference, however, I detected little interest on the part of the majority to table $E$. coli and begin again from scratch with some other organism. The enormous quantity of accumulated information about $E$. coli appeared to dictate that, despite its hazards, this was still the organism of first choice.

Letter reprinted in Recombinant DNA: Chimeras Set Free Under Guard, 93 Scr. 215, 215 (1976).

is Final EIS, supra note 9, at $\mathbf{v}$. 
latory or immunity systems for example might be ineffective against the organism, and the system's metabolic functions would thereby be disrupted. Fifth, changes in the properties of $\mathbf{E}$. Coli might increase its own ability to survive, perhaps improving its resistance to antibiotics and drugs. Such resistance is often genetically determined, and natural events such as the rapid spread of resistance to clinically important drugs over the last twenty years is evidence of the relative ease of transfer, by naturally occurring DNA recombinations, from one species of microorganism to another. ${ }^{16}$

The hazards and benefits of the research have been thoroughly discussed since it first became a source of controversy in 1973, when the Gordon conference highlighted the hazards which such research poses. ${ }^{17}$ Scientists found themselves in the limelight, exposed to concerns and criticism to which they had thought themselves immune. Yet a review of the history of regulation suggests that scientists remained in charge, that public participation was haphazard at best, that institutions for dealing with risky research gave it momentum rather than slowing it. Little organized opposition arose to the conduct of research at various academic centers and industrial labs around the country, with the exception of Cambridge, Massachusetts, ${ }^{18}$ for reasons related to the abstruseness of the issue to laymen, even well educated ones, and the effective lobbying efforts of scientists on the delicacy and potential benefits of this particular scientific enterprise. The threat was not seen as sufficiently pressing and tangible to excite significant opposition or to generate momentum for legislative action. The result was a go-slow attitude by the federal government toward regulation other than through NIH guidelines governing federally funded research, applicable to industry only on a voluntary basis. ${ }^{19}$ The legislative response to the controversy was a series of bills, based upon a variety of agency models, that proposed a licensing/inspection system, governed by a commission $^{20}$ or by the Secretary of Health, Education and Welfare (now Health and Human Services) ${ }^{21}$ and with several varying fea-

${ }^{18}$ Id.

17 See R. Hutron, supra note 11 , at 44 .

18 For a journalistic account, see Wade, Gene-Splicing: At Grass-Roots Level a Hundred Flowers Bloom, 195 ScI. 558 (1977).

10 Following a vote of the Recombinant DNA Advisory Committee (RAC) of $\mathrm{NIH}$, the transfer of DNA from one nonpathogenic organism to another was allowed in a $\mathrm{P} 1$ containment facility (reduced from a $\mathrm{P} 3$ requirement). See 4 RecombinanT DNA TECH'L BuLL. 30 (1981).

${ }^{20}$ See S. 1217, 95th Cong., 1st Sess. (1977) (introduced by Senator Kennedy). (1978).

${ }^{21}$ See H.R. 6158, 95th Cong., 2d Sess. (1978); H.R. 7418, 95th Cong., 2d Sess. 
tures. ${ }^{22}$ The final outcome was not legislation but rather continued reliance on the NIH guidelines. ${ }^{23}$

The recombinant DNA controversy highlights central characteristics which other areas of scientific research may possess, and which must be understood before considering regulatory alternatives. First, conducting the research creates risks of a sort which only insiders who are at the forefront of the work would initially spot. Thus, triggering an early warning system is dependent upon the scientists involved. ${ }^{24}$

Second, financial support, at its inception, comes primarily from the federal government, leading to a source of control through conditions on funding, and a subsequent problem of how to govern the governors, since peer review involves review by those typically already heavily committed to the field. ${ }^{25}$

Third, the research has possible commercial-industrial applications which promise a rapid deployment of the technology once perfected, giving rise to the problem of how to govern industrial research and its applications. The transition from research to commercial use has regulatory implications. Where a drug-related product is involved, agencies such as the Food and Drug Administration have ultimate control over the product's hazards (as opposed to hazards created by the research itself). ${ }^{28}$ Where laboratory workers are involved in private in-

22 For a discussion of the political and social history of the controversy, see generally S. Krimsky, Genetic Alchemy: The Social History of the Recombinant DNA CoNTROVERSY (1982). For a detailed look at legislative proposals to regulate rDNA research, see Swazey, Sorenson \& Wong, Risks and Benefits, Rights and Responsibilities: A History of the Recombinant DNA Research Controversy, 51 S. CaL. L. REv. 1019 (1978). For a detailed examination of the legislation, see Gulliton, Recombinant DNA Bills Derailed: Congress Still Trying to Pass a Law, 199 ScI. 274 (1978).

${ }^{23}$ Two recent examples of state legislation affecting recombinant DNA research include N.Y. Pub. Health Law $\$ \S 3220-3223$ (McKinney 1982) which requires a certification procedure for the operation of laboratories engaged in such research, but bases its regulation upon the NIH Guidelines: "If the National Institutes of Health guidelines are revised, the commissioner shall revise the regulations for the conduct of recombinant DNA activity accordingly." Id. \$ 3223. Thus, if the NIH downgrades its guidelines, New York will simply follow suit. Since the statute also preempts any local law or ordinance, it fails to present a significant regulatory alternative. A second example is MD. Pub. Health Code ANN. \$\$ 898-910 (1980). A license is required, and a Biohazards committee is to be appointed to monitor licensed projects. The NIH Guidelines are used again as the baseline for regulation. Sanctions are more elaborate, however, and the law allows for inspection of premises.

24 See infra note 91.

28 See J. Cole, S. Cole \& L. Rubin, Peer Review in the National Science Foundation 12 (1978) (citing report of the Office of Management and Budget).

${ }^{28}$ See Goldberg \& Miller, The Role of the Food and Drug Administration in the Regulation of the Products of Recombinant DNA Technology, 4 RecombinanT DNA TECH. BulL. 15 (1981). The authority of the Food and Drug Administration to regulate basic research, under its statutory mandate to assure the identity, strength, quality and purity of the products of food and drug research, is questionable. See Korwek, The 
dustry, OSHA has powers over workplace safety. ${ }^{27}$ Risks inherent in the conduct of the research, whether of accident or unforeseen result, are unregulated.

Given the present lack of federal controls, one is left with industrial self-regulation. Industry spokesmen try to forestall external regulation by contending that they have too much to lose to take chances in exploiting a new technology, ${ }^{28}$ a claim which may have some validity for the giant pharmaceutical companies, but less for the newer firms created to capitalize on the new technology. ${ }^{29}$ Critics of science, like Ravetz, contend that the incentive structure for good science is weakened in the industrialized setting: good science may not result because the careers of industrial scientists do not follow the same pattern as academic scientists. Publication is not as important, quality control is reduced, and peer pressure outside of the company is minimized. Given the differences in the norms of science within and outside industry, as well as in the incentive structures, it can be argued that industrial science will tend to be shoddy science, and risks are correspondingly greater. ${ }^{30}$ If dangerous work is undertaken within industry, what is the likelihood of whistleblowing by a scientist involved? Although some agencies like the Environmental Protection Agency (EPA) have offices responsive to whistleblowing complaints, ${ }^{31}$ the individual researcher still faces severe financial costs and possible damage to his career. $\mathrm{He}$ may be fired, may have substantial out-of-pocket litigation expenses, and may find himself out of his field. ${ }^{32}$ This suggests that a mechanism is needed which will provide a chance to evaluate the risks of the research before acceleration of the work into commercial settings occurs, a mechanism to deal with "the diminishing lead time between initial in-

NIH Guidelines for Recombinant DNA Research and the Authority of FDA to Require Compliance with the Guidelines, 35 Foon, Drug \& Cosmetics L.J. 633, 643 (1980).

${ }^{27}$ A team from the National Institute for Occupational Safety and Health (NIOSH) has recently inspected the facilities of Cetus Corporation in Berkeley, California, as a part of a study of the hazards of recombinant DNA technology. 1 GENETIC ENGINEERING LETTER 2 (1981).

28 See Industrial Applications of Recombinant DNA Techniques: Hearings on S. 1217 Before the Subcommittee on Science, Technology, and Space of the Senate Committee on Commerce, Science and Transportation, 96th Cong., 2d Sess. 57 (1980) (statements of Mr. Farley and Mr. Turner). (1973).

28 G. Ravetz, Scientific Knowledge and Its Social Problems 54-57

so $I d$.

81 The Office of Public Awareness within the EPA publishes information about how employees can blow the whistle without risking termination.

22 See Chalk, Maintaining Scientific Independence in a Bureaucratic Society, in 2 ScIence and Public Policy 11-21 (F. Sterrett \& B. Rosenberg eds. 1982); see also Holden, Scientist with Unpopular Data Loses Job, 210 Sa. 749 (1980). 
novation and widespread application."33

\section{B. Myths of Autonomy: The Limits of Self-Regulation in Science}

A central issue in the recombinant DNA controversy has been the efficacy of self-regulation in scientific research. If self-governance is effective, then scientists have a strong claim that their field deserves to be autonomous, and should remain free from outside regulation. It is difficult to assess the autonomy of a profession, given the subtle dynamics by which members establish norms and sanction colleagues. Certain general observations can be made, however, which suggest that the perceived autonomy of scientific research is largely a myth.

Autonomy is the basic characteristic of a profession. Professions possess substantial powers of self-control, gained either through professional associations, which foster group consciousness and integration while protecting members from outside interference and imposition of standards, ${ }^{34}$ or through informal networks of collegial relationships. ${ }^{35}$ Typical traits include self-determination of educational standards, laws affecting the profession shaped by the profession with little lay evaluation and control, and norms of practice often more rigorous than legal controls.

Science can be viewed as a profession, sharing common features with law and medicine. These features include a high educational requirement for entry, a monopolistic position regarding the performance of certain functions, control of admission standards, and authority of internal bodies over member conduct and subsequent hostility to any form of lay involvement. ${ }^{36}$ Science, like other professions, specializes in the development and application of complex knowledge considered vital to society's needs. This knowledge has an intellectual or scientific basis so that the activities of the group are subjected to and modified by theoretical analysis. The methods of science are formulated and accepted by the scientific community; the results of research are measured by criteria that the particular scientific specialty has developed. ${ }^{37}$ Science is thus a "self-defined enterprise, rarely, if ever, subject to external scru-

s3 L. Tribe, Ghanneling Technology Through Law 8 (1975).

34 See E. Friedson, Profession of Medicine 71-72 (1970).

ss See id. at 1901.

s6 See Ben-David, The Profession of Science and its Powers, 10 Minerva 362 (1972). See generally M. Larson, The Rise of Professionalism: A Sociological ANAlysis (1977); Cogan, Toward a Definition of Profession, 23 HaRv. Educ. Rev. 33 (1953); Parsons, The Professions and Social Structure, in Essays IN Socrological Theory PuRe AND APPlied 186-96 (revised ed. 1945).

s7 See G. RAVETZ, supra note 29, at 153-66 (1973). 
tiny."38 Extended specialized training in the corpus of knowledge of the profession is typical, and this socializing experience is longer and more encompassing than that of novitiates in other occupations. ${ }^{38}$

In science there is a system of monetary and psychic rewards symbolic of achievement and therefore ends in themselves. ${ }^{40}$ Income and prestige increase as professionalism increases. Like members of other professions, scientists strongly identify with their field, rarely desiring to change careers. ${ }^{41}$ Scientists are not motivated solely by altruism, but as it is with other professions, the institutional structure of scientific research has an ideological commitment to serve society. Science, unlike other professions, lacks a specific clientele to which it is accountable, and this absence of external checks leaves scientists without guidance regarding how to respond to either hazards arising out of research or harmful applications of the research product. ${ }^{42}$

Claims to autonomy are based upon three contentions: first, that the knowledge and skill of the profession's members are special and laymen cannot evaluate them; second, that professionals are responsible and work ethically without supervision; and third, that the profession can be trusted to act if one of its members acts improperly. ${ }^{48}$

Science can be distinguished from other professions in several ways. First, while the work of most professionals is defined by the needs of a particular client, the cause for which a scientist works is more diffuse. The dominant ideology of science is in fact that the scientist serves only the large goal of scientific truth in his pure research, a commitment to the value of advancing knowledge. ${ }^{44}$ In reality the motives of the scientist, like those of any professional, are a complex mixture of altruistic and egoistic behavior, with the ultimate goal being the receipt of recognition of priority of discovery, with its attendant psychic and career benefits.

Second, in science there is typically only one solution available for

38 Lappé \& Martin, The Place of the Public in the Conduct of Science, 51 S. CAL. L. REv. 1535,1536 (1978).

so See Goode, Encroachment, Charlatanism, and the Emerging Profession: Psychology, Sociology and Medicine, 25 AM. Soc. REv. 903 (1960).

${ }_{10}$ See Barber, Some Problems in the Sociology of the Professions, in The ProfesSIONS IN AMERICA 18 (K. Lynn \& Daedulus ed. 1965).

11 See Goode, supra note 39.

12 See Cournand, The Code of the Scientist and Its Relationship to Ethics, 198 ScI. 699 (1977). For an attempt to develop the foundations of an expanded ethic of scientific responsibility, based on increased predictive powers and historical sensitivity to the undesirable effects of scientific developments, see Twiss, The Problem of Moral Responsibility in Medicine, 2 J. Med. PHIL. 330, 365 (1977). See also Baram, Technology Assessinent and Social Control, 180 Scr. 465 (1973).

13 See E. Friedson, supra note 34, at 137 (1970).

44 See R. Merton, The Sociology of Science 340 (1973). 
a given problem. In business, markets can be expanded or new ones created; in law, no other lawyer generally is competing with the lawyer retained by the client to achieve a resolution of the client's problems. In science, no scientist has a monopoly on a line of research. As Gaston notes, "Competition in science is more like a race between runners in the same track and over the same distance at the same time."4s Original discovery is prized in science. In crowded, "hot" fields such as biology, competition tends to be particularly intense, creating strong incentives to violate the norms of science ${ }^{46}$ by engaging in secretiveness, hasty publication, fraud, or theft. ${ }^{47}$ The pirating of papers and falsification of data has become more visible in recent years as major cases of cheating in the biomedical area have emerged. ${ }^{48}$ Disruption of informal scientific etiquette may also occur as the result of intense pressures to achieve commercial applications of promising scientific techniques. ${ }^{49}$

Third, scientists in industry are usually seen as a subgroup with no counterpart in law or medicine. Since their incentives are more clearly determined by commitment to the industrial employer, their contribution to scientific knowledge is considered secondary to academic scientists, for reasons relating to the higher prestige of academic employment and the tension between employer demands and professional orientation in the industrial setting. ${ }^{\text {so }}$ Academic science has been seen as the paradigm for pure science, although it is apparent that most

15 Gaston, Secretiveness and Competition for Priority of Discovery in Physics, 9 Minerva 472 (1971).

46 For an elaboration of the "norms," see Cournand, supra note 42, at 701.

47 See id.

48 See Broad, Fraud and the Structure of Science, 212 Scr. 137 (1981); Culliton, Coping with Fraud: The Darsee Case, 220 ScI. 21 (1983); Schmaus, Fraud and the Norms of Science, 8 Science, Technology and Human Values 12 (1983); Schmaus, Fraud and Sloppiness in Science, 1 Perspectives on the Professions 1 (1981); Woolf, Fraud in Science: How Much, How Serious?, 11 Hastings CENTER REP. 9 (1981).

Such cheating may be increasing due to increased competitiveness, or perhaps more cheaters are being exposed as funding sources shrink. A change in attitude toward public exposure of cheating may also account for some differences between past rates of disclosure and the present flurry of cases. For an overview of the problem of fraud, see W. Broad \& N. WAde, Betrayers of Truth: FraUd and Deceit in the Halls OF SCIENCE (1982).

19 See Wade, University and Drug Firm Battle Over Billion-Dollar Gene, 209 ScI. 1492, 1493 (1980). Wade concludes: "the powerful forces of the profit motive clearly have the capacity to strain and rupture the informal traditions of scientific exchange." Id. at 1494.

Bo See Prager \& Omenn, Research, Innovation, and University-Industry Linkages, 207 Sci. 379 (1980); see also S. KLAW, The New BRAHMins: Scientific LifE IN AMERICA 71 (1968) (discussing the reasons why talented young scientists shy away from industry); W. KORNHAUSER, SCIENTISTS IN INDUSTRY: CONFLICT AND ACCOMMODATION 155 (1963). 
scientific areas have substantial and deepening industrial connections, and that the great majority of scientists earn their living in technical work. ${ }^{51}$ Recent evidence suggests that violations of scientific norms have occurred frequently in both academia and industry. ${ }^{\mathbf{6 2}}$

The concept of autonomous scientific research depends upon a distinction between "pure science" and its applications. Pure science traditionally has been defined as a method of investigating nature by the experimental method, seeking explanations with an aim of revealing the processes of natural phenomena. ${ }^{\text {s3 }}$ The distinguishing characteristic of pure science, in this view, is the end sought, the intentions of the scientist, an almost religious drive to "know." This focus has provided

S1 See G. RAvETZ, supra note 29, at 417. ("Even the interpenetration of science and industry can be traced back to the later nineteenth century, and can be seen as growing continuously since then.").

${ }^{82}$ Major rule infractions of the NIH Guidelines have occurred at the University of California, San Francisco, and at the Harvard Medical School. See Wade, Recombinant DNA: Warming Up for the Big Payoff, 206 ScI. 663 (1979). In another major infraction, a researcher at the University of California at San Diego cloned fragments from semliki forest virus instead of sindbis virus, for which he had permission. Then, without authorization, he used the viral genetic material generated by the cloning to infect mouse cells. See Wade, DNA: Chapter of Accidents at San Diego, 209 Scr. 1101 (1980); Wade, UCSD Gene Splicing Incident Ends Unresolved, 209 Sar. 1494 (1980). Kennedy, the scientist involved, was barred for two years from research support. In another case, a researcher at the University of California at Los Angeles used recombinant DNA techniques to link normal hemoglobin from a human donor to bacterial genes, then injected the material, combined with bone marrow from two subjects, into the patients' leg bones. His experiment violated both the NIH guidelines for recombinant DNA research and DHHS Guidelines for Experimentation on Human Subjects. See U.S. Health Panel Urges Disciplining of Blood Researcher, Wall St. J., May 29, 1981, at 37, col. 3 .

As commercial applications have proliferated, the new companies involved have had severe operational difficulties in complying with laboratory safety guidelines. At an inspection by NIOSH at Genentech in California, the inspection team concluded that the management "needs to implement safety and health, medical surveillance and emergency programs and procedures immediately." Quoted in 1 GENETIC ENGINEERING LETTER 2 (1981).

Bs Feibleman, Pure Science, Applied Science, and Technology in The TwoStory World: Selected Writings of James K. Feibleman 296 (H. Cairns ed. 1966). The process is not purely an inductive one, working from experimental data to theory. Rather, the process of hypothesis formation involves a complex "product of organized fantasy about the real world, tested constantly by an internal logic of necessity and an external logic of expectations both realized and disappointed. The theories are the mutations in this evolutionary ecosystem of mental species; testing by logic and by disappointed expectations is the selective process." Boulding, Science: Our Common Heritage, 207 ScI. 831 (1980).

84 See J. Bronowski, Science and Human Values 68 (1965) ("the society of scientists is simple because it has a directing purpose: to explore the truth").

Pure theoretical sciences are concerned with the discovery of natural law and the description of nature, and with nothing else. These sciences are conducted by men whose chief desire is to know, and this requires a detached inquiry-which Einstein has somewhere called "the holy curiosity of inquiry" and which Emerson declared to be perpetual. Such a detach- 
the ideological underpinnings for scientific resistance to attempts by bodies outside of science itself to regulate research. As with other professions, the claim of autonomy is based in part upon an ideological concept of service, which in the case of science is service in pursuit of knowledge. $^{\text {ss }}$ In our society, freedom of scientific inquiry, which depends upon a concept of pure science, is a cherished value; traditionally there has been thought to be less risk associated with pure science than with its large-scale technological applications. ${ }^{56}$

The pure science ideal pales, however, in light of the relationship between contemporary scientific research and its technological applications. The muddying of traditional distinctions has occurred in several ways. First, in problem solving, science must use advanced technology, with its physical tools becoming more complex and demanding. Electron microscopes and high-speed computers permit far more sophisticated measurements, but at a much greater cost. ${ }^{57}$ Maintenance of the instruments then comes to require a team of technicians as part of a "corporate," bureaucratic enterprise, a super-team effort. ${ }^{58}$ Second, the cost of both the tools and the staff require large maintenance funds, which come from outside sources, thereby affecting the independence of the researcher. Third, science often receives its assignments of problems

ment and such a pursuit are comparable in their high seriousness of purpose only to religion and art.

Feibleman, supra note 53, at 300.

ss See Technology and Science as "Ideology", in J. Habermas, Toward a RATIONAL SOCIETY 81 (1970). Applied science, following the conventional distinction, is "a system of concrete interpretations of scientific propositions directed to some end useful for human life." Id. at 36. Applied science and technology share a common goal: control or manipulation of the world. Technology, however, is a step removed from applied science: it is simply an increasingly developed use of instruments. Technology is an activity whose characteristic outcomes are material, rather than intellectual, with the intended purpose of expanding the physical range of the humanly possible. See McGinn, What is Technology? in Research IN Philosophy and Technology 179 (Durbin ed. 1978).

58 For a spirited defense of scientific inquiry that places the burden of proof on those who propose to regulate for any reason, see Cohen, When May Research Be Stopped?, 296 New. EnG. J. MEd. 1203, 1207 (1977). But see Bok, Freedom and Risk, 107 Daedalus 115, 123 (1978). For a statement of the assumption that pure science is less risky than its applications, see Hadden, Regulation of Recombinant DNA Research, in M. RICHARDs, Recombinant DNA: Science, Ethics and Politics 216 (1980).

B7 See G. RAvETZ, supra note 29, at 194-99; Jonas, Freedom of Scientific Inquiry and the Public Interest in Regulation of ScIENTIFIC INQUiRy 33, 36 (K. Wulff ed. 1979).

B8 See G. Ravetz, supra note 29, at 44-47; see also Cavalieri, Science as Technology, 51 S. CaL. L. REv. 1153, 1165 (1978) ("scientific research has become a camoflauged superteam effort, comprised of a team or teams already existing in the research laboratory coupled to a commercial team or teams supplying the instrument'). 
to select for solution from the state of the relevant technology, ${ }^{50}$ both because it is the technology of tools that decides what areas can now be investigated practically and because the demands of a technologically developing area with commercial promise create a demand for research. ${ }^{60}$ Science has come to depend upon successful applications of pure research to enable scientists to argue for continuing support. There is thus a continual spiral of support and application.

In any event, the distinction between thought and action cannot serve to immunize pure science from regulation. The process of scientific experimentation, as part of the process of hypothesis testing, articulation, and refinement, is action. Theory and practice are inseparable. ${ }^{61}$ One might still contend that it is the intent of the researcher that is determinative-exploring an abstract question involved in his field, or seeking practical applications-but this distinction breaks down in the recombinant DNA context, as more researchers wear the hats of both pure scientists and industry researcher. ${ }^{62}$

59 See Boulding, supra note 53, at 833 ("Measurement is a function of technology, and it could well be indeed, that technology has contributed more to science historically than science has to technology. There is at least a constant feedback between them.").

- 0 See G. RAVETZ, supra note 29 , at 93 (contending that most of the science practiced today has at least a speculative relationship to a potential technology).

61 Legal scholars have muddled this area by distinguishing between regulation of health and safety hazards resulting from technological applications, and regulation of "basic" research, or "original investigations for the advancement of scientific knowledge-which do not have specific (practical) objectives' or ends in view." Delgado \& Millen, God, Galileo, and Government: Toward Constitutional Protection for Scientific Inquiry, 53 Wash. L. Rev. 349, 352, n.21 (1978) (quoting National Science BOARD, SCIENCE INDICATORS 53 (1975)); see also Green, The Boundaries of Scientific Freedom, HaRv. Newsletter on Sci. Tech. and Human Values, June 1977, at 17 (referring to experimentation as action). Robertson is surely right that "[t]he presence of physical activity in research or other expression may implicate other state interests that justify limitation, but the semantic characterization of experimentation as conduct is not a magical property that excludes First Amendment protection." Robertson, The Law of Institutional Review Boards, 26 UCLA L. REV. 484, 505 n.127 (1979); see also Davidson, First Amendment Protection for Biomedical Research, 19 ARIz. L. REv. 893 (1977).

o2 Freedom of scientific inquiry has been raised as a barrier to regulation of scientific research, protecting not only freedom of thought or speech, but also action, which in the doing of science is empirical observation and the testing of hypotheses. A constitutional argument can be made that regulation of research based upon political or social grounds is impermissible. See Delgado \& Millen, supra note 61. Experimentation, as an integral part of the scientific process of hypothesis formulation and evaluation, has been likened to news gathering, which falls under first amendment protection. See Branzberg v. Hayes, 408 U.S. 665, 705 (1972) ("academic researchers" included among those performing an "informative" function).

The speech/action dichotomy is too crude to provide an analytical framework for the regulation of science, although the similarity of experimentation to action, or conduct, has been noted, arguably with resulting loss of first amendment protection. Emerson has been a principal advocate of the speech/action distinction. See T. EMERSON, The System of FREEDOM of EXPREssion 8, 17 (1970); see also Ferguson, Scientific 


\section{A Starting Point for Analysis}

The paradigm case suggests that scientific research may in some contexts create substantial risks, that the claims of pure science to autonomy are not justified, and that a systematic theory of institutional regulation of research hazards is needed. The recombinant DNA controversy presents sharply the question of uncertainty in research. The following hypothetical situation provides a specific setting in which the general claims of this article can be tested. ${ }^{63} \mathrm{~A}$ university laboratory has begun research on a rare African disease, and the scientists involved plan to use recombinant DNA techniques to explore the nature and the mechanisms by which the disease functions. The rDNA technique has just been recognized as possibly revolutionary, and the media has run one or two stories suggesting that hazards exist as well. Individuals in the community in which the university is located, and adjoining communities, express concern over the hazards of such work. No federal agency presently claims jurisdiction over such research. No tort damage action is available, since no identifiable harm has yet occurred. Talks with university administrators have proven difficult to arrange and produce no change in the planned research. The facility is in an area of the community zoned for research, and operates according to present state regulations governing laboratory protocols.

Inquiry and the First Amendment, 64 CORNELl L. Rev. 639, 650-51 (1979); Green, supra note 61, at 17-18. Since science in all fields requires experimentation as a part of progress, just as most areas of expression require some activity as part of generating and communicating ideas, physical activity by itself is not a useful test for demarcating the boundaries of protection. See L. TrIBE, American Constitutional Law 598601 (1978); Henkin, The Supreme Court 1967 Term-Foreword: On Drawing Lines, 82 HaRv. L. Rev. 63, 79 (1968); Robertson, supra note 61, at 505. We are brought back to a sphere of regulation based upon risks to individual health and environment, rather than upon the content of research. Regulation based upon the police power, protecting the public health and safety, raises few significant constitutional problems. See Delgado \& Millen, supra note 61, at 380. The police power enables states to legislate and take action to promote "the peace, good order, morals, and health of the community," Munn v. Illinois, 94 U.S. 113, 145-46 (1876). It is, however, subject to some constitutional limits. See, e.g., Panhandle E. Pipe Line Co. v. State Highway Comm., 294 U.S. 613, 622 (1935); Eubank v. Gity of Richmond, 226 U.S. 137 (1912). Where a line of research is inherently hazardous, appropriate action under the police power is permissible.

6s An accident at Plum Island, the site of a Department of Agriculture Animal Disease Center off Long Island, New York, produced the kind of situation upon which the hypothetical is based. An outbreak of foot-and-mouth disease occurred in September, 1978. It is not known how the virus escaped from the research facility, the equivalent of a P4 laboratory like that in Fort Detrick, Maryland. Neighboring communities on Long Island expressed concern about the research at the facility because of a plan to begin research on Rift Valley fever, an exotic African disease which had recently developed into a health menace in Egypt. See Wade, Accident and Hostile Citizens Beset Animal Disease Laboratory, 202 Scr. 723 (1978). 
The problem presents two issues: how to evaluate institutional mechanisms for dealing with the potential hazard, and how to assign the burden of proof as to the nature and extent of the hazard.

\section{Models for Governing Public Risks}

\section{A. Criteria for Evaluating Risk-Governing Models}

Four basic criteria for comparing approaches to the regulation of research hazards can be articulated, considering as a paradigm case recombinant DNA research and its history. ${ }^{64}$ It is proposed that any model for governing public risks can be evaluated in light of its effectiveness in braking the momentum of research areas, counteracting bias of those involved in the risk-creating activity, generating relevant and accurate information, and promoting public participation.

\section{Provision of a Trigger/Brake}

The recombinant DNA controversy furnishes ample evidence of the momentum which can accumulate as a promising line of research develops. ${ }^{6 s}$ Critics have pointed out that risk assessment procedures have not been carried out in many cases before the expansion of research in the area. ${ }^{68}$ The prevalent attitude in the scientific commu-

64 Tribe has proposed five objectives of technology assessment: the general welfare; the preservation of options (with irreversibility a primary criteria); the burden of uncertainty as it relates to generating information about secondary effects; the creation of constituencies; and the achievement of consistency. L. TRIBE, Ghanneling TechNology Through Law 19-28 (1973). These are valuable goals in a broad sense, but are not directly relevant in testing institutional capacities. Rather, they offer a mix of normative and practical considerations for policymaking.

For a look at criteria for evaluating procedures in the nuclear power context, see Cramton, A Comment on Trial-Type Hearings in Nuclear Power Plant Siting, 58 VA. L. REv. 585 (1972) (suggesting accuracy, efficiency and acceptability as three central criteria). (1979).

6s Wade, Recombinant DNA: Warming Up for the Big Payoff?, 206 Scr. 663

${ }_{68}$ See Letter from Philip Bereano to Dr. Donald Fredrickson (Oct. 8, 1979), reprinted in 5 Recombinant DNA Research 346 (1980) (HEW Documents Relating to "NIH Guidelines for Research Involving Recombinant DNA Molecules," January 1979 - January 1980) [hereinafter cited as HEW Documents].

That assessment has been recently reiterated by a knowledgable student and critic of the rDNA controversy:

NIH's risk-assessment plan has been meager in comparison to the anticipated scope of applications for gene splicing. Scientists have shown little concern for experimental protocols that examine risks. Moreover, as public pressure for restraint in biotechnology waned, less importance was placed on risk-assessment programs.

Krimsky, Science Perverted: Can It Happen Here?, 13 Hastings Genter Rep. 42, 43 (1983). 
nity - that dangers have been overrated-may be due as much to the tremendous progress being made in research as to new experiments which clearly and definitively answer questions. ${ }^{67}$ Risk assessment experiments have revealed that the magnitude of hazard was higher than originally expected: bacteria containing recombinant DNA remain alive in humans 500 times longer than previously estimated; ${ }^{68}$ another study reported that a recombinant gene containing a cancer virus can produce tumors in mice. ${ }^{69}$ These studies had serious implications for rDNA research, suggesting that controls should be maintained rather than weakened. ${ }^{70}$

It is therefore necessary to provide a means to trigger a "governor"- - a method by which the expansion of research can be checked in order to allow more careful evaluation of risks, benefits, and future developments. Public control over funding has often been suggested as an adequate brake on potentially hazardous research.$^{71}$ Such funding decisions, however, do not affect most industrial research. Thus, as more basic research is done either by industry or through industrialacademic cooperation, the controls possible through federal funding will be further weakened. In addition, federal funding decisions are presently determined primarily by the values of the members of the scientific community. ${ }^{22}$ Participation by nonscientists in the peer review funding process has been suggested as a means of incorporating other values into the priorities of funded research, but little movement in this direction is evident. ${ }^{73}$

What is needed is "a more deliberate, explicit, and somewhat more pessimistic consideration of the area of uncertainty as to potential

${ }^{67}$ This viewpoint was most recently expressed by Gershon, Should Science Be Stopped: The Case of Recombinant DNA Research, 71 PUB. INTEREST 3 (1983).

es See Levy \& Marshall, 2 Recombinant DNA Tech. Bull. 77 (1979).

69 See Israel, Chan, Rowe \& Martin, Molecular Cloning of Polyoma Virus DNA in Escherichia coli: Plasmid Vector System, 203 ScI. 883 (1979); Chan, Israel, Garon, Rowe \& Martin, Lambda Phage Vector System, 203 ScI. 887 (1979).

${ }^{70}$ See Rosenberg \& Simon, Recombinant DNA: have recent experiments assessed all the risks?, 282 NATURE 773 (1979). For a critical view of the risk assessments done to date, see S. KRIMSKY, supra note 22 , at $215-84$, suggesting that experiments purporting to show zero risk can be faulted on several grounds.

21 See Baltimore, Limiting Science: A Biologist's Perspective, 107 DaEdalus 37, 44 (1978).

${ }_{72}$ See Dworkin, Biocatastrophe and the Law: Legal Aspects of Recombinant DNA Research, in The Recombinant DNA Debate 219 (D. Jackson \& S. Stich, eds., 1979); see also Baram, The Social Control of Science and Technology, 47 Denv. L.J. 567,573 (1970).

${ }^{73}$ See the remarks of Steven Schwarcz, reprinted in Symposium: Curbing Ignorance and Arrogance: The Science Court Proposal and Alternatives, 19 JURIMETRICS J. 387, 425 (1979) [hereinafter cited as Symposium]. 
hazards, ${ }^{, 74}$ triggered by some mechanism to focus attention on the putative hazards of research and to mobilize resources for further inquiry, while dampening the momentum which a promising line of research accumulates.

\section{Counteraction of bias}

An effective scientific review mechanism must provide a method of evaluation without institutionalizing the biases of the major actors involved in the research - those with a vested interest in its continuation. ${ }^{25}$ Review boards such as those charged with evaluating funded research involving human subjects provide an example of a device with the potential to allow substantial lay decisionmaking power at the initial stages of research on a case-by-case basis, although the actual impact of lay members has been questioned. ${ }^{76}$ In scientific research not involving human subjects, bio-safety committees have in a few cases exercised power over a line of research where violations were alleged, ${ }^{77}$ but such committees are apparently dominated by scientists favorable to the research. ${ }^{78}$ Some means of interjecting new perspectives into scientific decisionmaking can serve a valuable function in altering scientists' perspectives about their responsibilities and the nature of the risks inherent in their research. ${ }^{79}$

\section{Generation of Relevant and Accurate Information}

The institutional mechanism chosen must lead to a more complete record on the factual issues bearing on a line of research by creating incentives for parties to produce information. The mechanism should focus not only upon the risks of the particular line of research, but also upon alternate means of achieving the same results at which the research aims. Sufficient resources must be available for opponents of the (1981).

${ }^{74}$ Harold Green, quoted in L. Cavalieri, The Double-Edged Helix 131

${ }^{25}$ For a general discussion of the problems of counteracting bias, see Schneyer, Informed Consent and the Danger of Bias in the Fornation of Medical Disclosure Practices, 1976 WIs. L. REv. 124.

${ }_{78}$ See DuVal, The Human Subject Protection Committee: An Experiment in Decentralized Federal Regulation, 1979 A.B.F.J. 571.

${ }_{77}$ See Wade, DNA: Chapter of Accidents at San Diego, 209 Scr. 1101 (1980).

78 Id.

70 For a well-developed argument for lay participation in scientific research of all kinds, see Holman \& Dutton, A Case for Public Participation in Science Policy Formation and Practice, 51 S. CAL. L. Rev. 1505 (1978); see also L. TRIBE, supra note 64, at 35; comments by D. Nelkin, reprinted in Symposium, supra note 73, at 420 . 
research to gather information. ${ }^{\mathbf{8 0}}$

\section{Promotion of Public Participation}

The extent of public participation has often been cited as a goal against which to measure various approaches to technological problems. ${ }^{81}$ Such participation offers several benefits. First, it may lead to more accurate resolution of the issues by bringing in alternative viewpoints and unexpected perspectives. ${ }^{82}$ Increased accuracy is by no means an inevitable result of increased participation, but requires careful control by a judge, an agency, or a mediator to ensure proper representation and adequate resources for parties to facilitate their representation. ${ }^{83}$ Second, it may increase the confidence of citizens in the fairness of decisionmaking, whether private or government, that affects their lives. ${ }^{84}$ It may even be seen as a kind of crude political process in which a vote (or at least a protest) can be cast. ${ }^{85}$ Third, participation is

$80 \mathrm{NIH}$ drafted an environmental impact statement (EIS) in response to the controversy over the research, court challenges, and criticism by legal scholars. See NIH, Environmental Impact Statement on NIH Guidelines for Research Involving Recombinant DNA Molecules (Oct. 1977). However, the statement failed to address the range of risks and alternatives in a realistic way. See Chalker \& Catz, A Case Analysis of NEPA Implementation: NIH and DNA Recombinant Research, 1978 DUKE L.J. 57, $61 \& 95$.

One may be cynical generally about the effect of impact statements on the behavior of those proposing activities. As critics have observed in a study of one federal agency: "NEPA had not greatly affected either the types of alternatives being considered or who and what influenced the formulation and evaluation of these alternatives." Hill \& Ortolano, NEPA's Effect on the Consideration of Alternatives: A Crucial Test, 18 NAT. Resources J. 285, 311 (1978).

is See D. Nelkin, Technological Decisions and Democracy: European Experiments in PUblic Participation (1977).

${ }^{82}$ Many of the values fostered by increased participation have been noted in the administrative law context. See, e.g., Bonfield, Representation for the Poor in Federal Rulemaking, 67 Mich. L. REv. 511, 511-22 (1969); Johnson, A New Fidelity to the Regulatory Ideal, 59 GEO. L.J. 869, $875-76$ (1971). But as Stewart observes in The Reformation of American Administrative Law, 88 HARv. L. REv. 1667, 1777 (1975), the expanded public interest representation model does not guarantee exposure and analysis of relevant issues. See Hudson River Fisherman's Ass'n v. FPC, 498 F.2d 827 (2d Cir. 1974) (tidal flow in Hudson at project site, increasing potential danger to fish life, not discovered until after ten years of agency and court proceedings). "The power to start a serious and credible technical controversy lies in few hands, notably the environmental and consumer groups, and some prestigious scientists who have good access to the nation's mass media [citation omitted]. Controversies which come from less orthodox sources have trouble gaining credibility in higher circles." A. MAzur, supra note 4 , at 131 .

${ }^{83}$ Proposals for funding public representation have often been made. See Lazarus \& Onek, The Regulators and the People, 57 VA. L. REv. 1069, 1097-1104 (1971). Rewards of attorney's fees in private litigation can also provide a valuable incentive for public interest litigation.

Bt See Cramton, supra note 64, at 593.

so See Comment, The Role of the Judiciary in the Confrontation with the Problems 
intrinsically valuable, acknowledging the right of individuals to know about risks affecting their well-being. ${ }^{86}$ Participation is thus an important goal, as it has a utilitarian or efficiency justification (it may lead to better science in some cases), a political justification (it legitimates a line of research), and a normative justification (it furthers the public's right to know about public risks). ${ }^{87}$

Public participation in scientific decisionmaking, particularly at the early stages of development of a line of research, usually has been limited or nonexistent. ${ }^{88}$ While varying degrees of public involvement occurred in the rDNA controversy, for example, through public hearings at the local government level in Cambridge, Massachusetts and other localities, severe limitations on that participation have been apparent. Participation has been sought after research agendas were set; mechanisms for involving the public have been reactive, commencing well after the problem areas have emerged; participation, requiring resources to be meaningful, has usually not included less privileged groups or individuals; and participation at its best has been advisory rather than directive, rarely granting non-scientists substantial say over a line of research or a newly emerging technology ${ }^{80}$

It is therefore necessary to design a mechanism that can generate information at the outset from those most familiar with and best able to analyze potential hazards, that is sufficient to trigger broader scrutiny

of Environmental Quality, 17 UCLA L. REv. 1070 (1970). Tribe has pointed out that it is an error to assume that "[c]hange which is initiated through litigation is inherently less democratic than change in which legislative or administrative bodies take the dominant role." Tribe, Seven Pluralist Fallacies: In Defense of the Adversary Process - A Reply to Justice Rehnquist, 33 U. Miami L. Rev. 43, 53 (1978). He refers to Archibald Cox's statement that a citizen feels little more of a sense of participation in the legislative process than in the judicial. See A. Cox, The Role of the Supreme CoURT In AMERICAN GOVERNMENT 116 (1976).

${ }^{86}$ See McLachlan, Democratizing the Administrative Process: Toward Increased Responsiveness, 13 ARIz. L. REv. 835 (1971); Tribe, Policy Science: Analysis or Ideology, 2 Phil. \& Pub. Affairs 66, 83 (1972).

87 The recognition of the importance of participation values in litigation can be found in Thibaut, Walker, LaTour \& Houlden, Procedural Justice as Fairmess, 26 Stan. L. Rev. 1271 (1974) and Thibault \& Walker, A Theory of Procedure, 66 CALIF. L. REv. 541 (1978). But see Simon, The Ideology of Advocacy: Procedural Justice and Professional Ethics, 1978 WIs. L. REv. 29, 95 ("not only does the judicial proceeding tend to be held in low esteem by the population as a whole, but it is even less well regarded by those who have actually had the experience of participating in it directly as litigants").

s8 See Holman \& Dutton, supra note 79.

80 Protests against science may be protests against the power relationships associated with it, "less against specific technological disputes than against the declining capacity of citizens to shape policies that affect their interests; less against science than against the use of scientific rationality to mask political choices." D. Nelkin, reprinted in Symposium, supra note 73, at 420. 
by those whose interests have not vested in the particular line of research, and that can suggest an appropriate regulatory response.

\section{B. Alternative Models}

Institutional models to cope with controversies of a "science and society" nature have been spawned, in the academic literature if not in reality, in contemporary controversies such as those surrounding nuclear power generation, Laetrile, and recombinant DNA research. The models fall into three broad categories, based upon their primary purpose: investigation, making a preliminary determination of the nature and extent of the risks and benefits involved; resolution, deciding whether and how to proceed with a hazardous activity in areas of scientific uncertainty; and, control, regulating the activity on a continuing basis. These purposes are sequential in most cases, since the nature and extent of the hazard must be identified prior to a decision on how to proceed and control can best result from an informed decision on the acceptable course of action. Regulation of novel hazards, however, must proceed in the face of uncertainty, with investigation and decisions continually reshaping the extent and nature of regulatory control.

A second way in which to compare alternative models is based upon the values of the participants: the elitist models, in which the values of scientists predominate, and the public models, in which the "public" can be said to participate and exercise control. Certain models, such as the legislative Science Court, ${ }^{90}$ fall clearly into a particular category, while others, such as the civil damage action, serve several purposes and incorporate both expert and non-expert viewpoints. Even models that appear to straddle categories, however, tend to be dominated by one source of values while serving only one principal purpose.

\section{Elitist Investigation Models}

Early discovery of hazard is an essential purpose of any mechanism for dealing with scientific controversy because a promising line of research can quickly develop beyond the point of easy control.

Scientific discovery and disclosure of problem areas, within the informal framework of scientific norms of self-governance, is presently the only existing source of information. A scientist working at the frontiers of a new development may thus be sufficiently troubled by a potential development to raise questions publicly. As an early warning system, responsible scientific norms may aid in the assessment of new

90 See infra note 100 and accompanying text. 
hazards. The reliance on such self-governance has at its root the concept of scientists as professionals, subject putatively to the higher norms of professional practice. They have a service orientation toward society at large, and their primary goal is the pursuit of knowledge for its own sake. According to the argument, we should therefore trust scientists to police themselves, to recognize new problem areas, and to point them out as objects of needed regulatory action. ${ }^{91} \mathrm{~A}$ warning by one researcher, however, does not imply a willingness on the part of those working in the area to stop temporarily or to listen to a colleague's reservations. $^{92}$ In the recombinant DNA controversy the field has been divided, with most researchers in favor of proceeding with research under the NIH guidelines and a minority adamantly opposed to even the NIH guidelines. Once a research area is "hot," scientists, like any professionals, will face a conflict between norms of caution and their interest in career advancement and recognition by their peers. Self-regulation may work in promoting good as opposed to shoddy science, ${ }^{93}$ but it is the risks inherent in good as well as shoddy research that cause concern.

A formal scientist/government early warning system has been proposed to surmount the limits of reliance on informal sources of information from practitioners. Expansion of the mandate of the Office of Technology Assessment (OTA) has been suggested as a way to provide a mechanism for spotting emerging controversies. The OTA was created legislatively in 1972, and has come to provide supplemental analysis to legislative committees concerned with science and techology. OTA has tended to focus on technological applications rather than basic research. It has been primarily reactive, responding only when asked by Congress. While it has the advantage of a staff and a continuing mandate to look broadly at scientific developments as they occur, it is likely

${ }^{91}$ See Stich, The Recombinant DNA Debate: Some Philosophical Considerations, in The Recombinant DNA Debate, supra note 72, at 200-01.

${ }_{82}$ Stich noted that the scientists involved in the Asilomar conference took an unprecedented step in pointing out the hazards of their research:

Their actions have been widely and justifiably praised as an exemplar of moral responsibility in the scientific community. Yet . . . two years after the Asilomar conference, it is an open secret that a number of the scientists who are responsible for Asilomar are disillusioned, and perhaps a bit bitter. ... Privately, a number of the scientists who participated in the Asilomar Conference now say that if they had it to do over again, they would have "kept their mouths shut" and never brought their concerns about safety to the attention of a wider audience.

Id.; see also Boone, When Scientists Go Public With Their Doubts, 12 Hastings CENTER ReP. 12, 16 (1982).

${ }^{\circ 3}$ See G. RAvetz, supra note 58 , at 49. 
to act well after a line of research is underway. One suggestion has been to expand OTA's mandate and establish long-term relationships with academic scientists who could "provide a sophisticated early warning system, by pointing to, and conducting initial evaluations of, significant new scientific discoveries."94 The proposal has merit, assuming congressional willingness to expand OTA's staff and budget; it depends, however, upon an assumption that a scientist's career will not be sidetracked by expending his energy on such assessment studies rather than on basic research. It may be that only the mediocre will develop such relationships while the top scientists continue to pursue the interesting questions at the cutting edges of their fields.

Simon Ramo recently has proposed an administrative model, a sort of "technological FBI," in which scientific experts would be placed in one administrative unit to deal with "technological negatives." would lead to efficiency and flexibility of organization, obviating the need for Congress "to perceive a new danger and launch still another agency to handle it." scientists that work for such an agency do any better than current administrative agency staffs at detecting hazards at the forefront of scientific and technological developments? Will not the need for specialized knowledge about different categories of hazards-biological, ecological, drug-related-require distinct units which will quickly come to resemble the research components of existing agencies? The fundamental problem is that congressional action is required to set up yet another agency, albeit with a broader mandate, in an area that has proven highly resistant to administrative control and at a time when deregulation is a principal political goal.

\section{Public Investigation Models}

Few precedents exist for such an approach, although the Cambridge, Massachusetts hearings on recombinant DNA research are often cited as an example. ${ }^{97}$ In 1976 a citizen review board was estab-

* Capron, Reflections on Issues Posed by Recombinant DNA Molecule Technology, 265 ANN. N.Y. ACAD. Scr. 71, 75-77 (1976). A more elaborate suggestion was that a joint commission be formed, chosen by the President and Congress, using the office of the Science Advisor to channel scientific expertise, and the Office of Technology Assessment for assessment experience, and the executive agencies and congressional committees for public reaction. See Grobstein, Recombinant DNA Research: Beyond the NIH Guidelines, 194 ScI. 1133 (1976).

842 (1981).

${ }^{95}$ Ramo, Regulation of Technological Activities: A New Approach, 213 Scr. 837,

* Id.

or See supra note 18 and accompanying text. 
lished to advise the Cambridge City council, based on the principle that a citizen group could investigate a problem area and reach a decision. ${ }^{98}$ Yet insofar as academic scientists focused the agenda on short-term health harms and safety measures, such a public investigatory approach was essentially "structured discussions over predetermined policy with few real options." many areas of technological controversy usually have involved public participation at the decision level, primarily as a means of gaining public approval for a decision whose merits had already been prejudged.

\section{Elitist Resolution Models}

The elitist resolution models have attracted the most attention from commentators, with a plethora of suggestions for allowing expert scientists, through various institutional formats, to reach agreement on issues of risk and thereby promote public consensus and legislative action.

The legislative Science Court, first proposed by Arthur Kantrowitz, allows a scientific or technologial controversy, such as the recombinant DNA dispute, to be evaluated by a panel of expert judges after an adversarial presentation of evidence is made. Such an institution, according to its proponents, ${ }^{100}$ would separate fact from values in a controversy, separate the functions of the judge from those of the advocate, and provide an open, public procedure with the process and conclusions available to all.

The variations on Kantrowitz's Science Court model include a Technical Review Board, ${ }^{101}$ a Technological Magistrature, ${ }^{102}$ and Certified Public Scientists. ${ }^{108}$

A variety of criticisms can be leveled against such a Science Court

88 See Letter from J. Sullivan, City Manager, to City Council of Cambridge, Massachusetts (August 6, 1976): "Decisions regarding the appropriate course between the risks and benefits of potentially dangerous scientific inquiry must not be adjudicated within the inner circles of the scientific establishment . . a lay citizens group can face a technical scientific matter of general and deep public concern, educate itself appropriately to the task and reach a fair decision." [copy on file at University of Pennsylvania Law Review].

Nelkin \& Pollak, Problems and Procedures in the Regulation of Technological Risk, in SocIETAL RISK AsSESSMent 246 (R. Schwing \& W. Albers ed. 1980).

100 See Kantrowitz, The Science Court Experiment, 13 TRIAL 48 (1977) and references cited therein.

101 See B. Ackerman, S. Ackerman, J. Sawyer, \& D. Henderson, The UnCERTAIN SEARCH FOR ENVIRONMENTAL QualTTY 156 (1974). at 34 .

${ }_{102}$ See Bugliarello, A Technological Magistrature, Bull. ATom. Scr., Jan. 1978,

103 See Glick, Reflections and Speculations on the Regulation of Molecular Genetic Research, 265 ANn. N.Y. AcıD. Scr. 178, 189 (1976). 
model and its variations. It tends to confuse values, obscuring the real policy choices under a camoflauge of "objective" scientific fact. ${ }^{104}$ A decision by the Science Court may carry too much weight for government decisionmakers because of the elaborate nature of the process and the presumed validity of the results. ${ }^{105}$ The authoritative determination of a scientific issue by a governmentally established body may hurt scientific independence as well, because disputed issues are normally resolved by the norms of the scientific community itself over time. ${ }^{108}$ Finally, the areas that are likely to be presented for resolution are either going to be in the "penumbra of unsettled scientific questions or in the area of public policy." In neither case is a Science Court the appropriate forum for resolution. ${ }^{102}$ While such a model may be worth trying on an experimental basis to ascertain whether the criticisms are as serious as they appear, it is unlikely to serve sufficiently the goal of an early warning system, although it may provide clarification of factual disputes over a scientific controversy. ${ }^{108}$

A scientific "town meeting" model, following the precedent of the Asilomar Conference on the hazards of recombinant DNA research, ${ }^{109}$ has been offered as a means by which a profession can render a decision in a controversial area within its specialty. It is essentially a more organized and structured version of self-regulation through norms and social interaction. The goal is to achieve a professional consensus through regular meetings. As a model, such an approach is severely limited by its lack of enforcement power, its inability to respond in a timely manner, and the likelihood of reaching consensus while avoiding real issues. Even if a consensus is achieved on a substantive point, it does not bind those who disagree other than through moral suasion. ${ }^{110}$ Such meetings are likely to be called well after interest in, and work

104 See Nelkin, reprinted in Symposium, supra note 73, at 421 ("The belief that science is inherently removed from political considerations and that scientists are, therefore, political celibates is a longstanding one, but in the present social context of science, it is an anachronism.").

${ }_{105}$ See generally Martin, The Proposed Science Court, 75 Mrch. L. Rev. 1058 (1977); Nelkin, Threats and Promises: Negotiating the Control of Research, 107 DaEDulus 191, 203 (1978).

${ }_{106}$ See Loevinger, reprinted in Symposium, supra note 73, at 393.

107 See Gross, reprinted in Symposium, supra note 73, at 452.

108 See Martin, supra note 105, at 1090-91.

109 For journalistic accounts of the conference, see J. Goodfield, Playing God: Genetic Engineering and the Manipulation of Life (1979); M. Rogers, BiOHAZARD (1977); N. WADE, The Ultimate ExPERIMENT (1979).

${ }_{110}$ See Dworkin, Science, Society, and the Expert Town Meeting: Some Comments on Asilomar, 51 S. CAL. L. REv. 1471, 1479-80 (1978) ("Moral suasion is wonderful, but it is not enough ... [t] the real town meeting gained its legal as well as its moral, authority from the existence of consensus. No such consensus exists with respect to the social issues posed by modern science."). 
on, a line of research has begun, so that commitments to that work are entrenched. Like the New England town meeting, the consensus may be based upon the dominant values and norms of those most favorable to the research, having all of the problems that professional self-regulation normally possesses. ${ }^{111}$

\section{Public Decision Models}

Decision models oriented toward lay rather than expert values range from decentralized models like civil actions in tort to proposals for "decision boards," operating within the executive branch, comprised of educated laymen.

\section{a. Compensatory Tort Actions}

A traditional litigation model based on tort suits for damages done to person or property is available. Such tort litigation was once seen as a powerful tool for technology assessment, forcing risk-creating activities to internalize the costs they imposed on society. ${ }^{112}$ If harm occurred to a laboratory worker, or a neighbor, because of hazardous research, then the person or his estate could sue the laboratory, the university, the industry-whichever actor was legally responsible. ${ }^{113}$ In theory, the specter of such liability for damages would provide a substantial deterrent against the dangerous practices, as well as an incentive for the risk-creator to take greater care. ${ }^{114}$ This model thus protects common law entitlements to liberty and property, while theoretically also furthering economic efficiency.

In reality, in the context of modern hazards characterized by long latency periods and complicated causal connections, tort liability is an ineffective tool for assessing technology. First, the diffuse nature of the harm may result in failure to generate adequate incentives: the prodigious problems of proof of both damages and causation will deter such suits. The escape of nuclear radiation, or a bacteria altered through

111 The fear of domination by a majority was noted by Madison in THE FEDERALIST No. 10, at 58 (Modern Library College ed. 1937).

112 See Katz, The Function of Tort Liability in Technology Assessment, $38 \mathrm{U}$. Ginn. L. Rev. 587 (1969); Note, The Cost-Internationalization Cașe for Class Actions, 21 Stan. L. Rev. 383 (1969).

113 Such a suit has been brought against the University of Birmingham, where a laboratory using smallpox toxins caused the death of a university photographer whose office was above the lab. See Hawkes, Smallpox Death in Britain Challenges Presumption of Laboratory Safety, 203 Scr. 855 (1979).

114 The law and economics literature treats this problem in considerable detail. See generally G. Calabresi, The Costs of Accidents (1970), particularly the chapters on general deterrence. 
recombinant DNA techniques, may cause long-term effects that can only be discovered by an epidemiological analysis twenty years after the fact. ${ }^{115}$ This low-grade effect, plus the extended latency period for many diseases such as cancer, poses severe causal complexities. Gourts have struggled to alter traditional rules of causation to deal with the problems of multiple causation and long latency periods. ${ }^{116}$ Where the damage can be linked to both natural and man-made causes, however, it is unlikely that even altered causation rules can handle the complexity with sufficient consistency to provide the necessary deterrent against highly uncertain risks.

Second, the effective representation of future generations, seemingly essential given genetically damaging and irreversible effects, may be hard to secure in the traditional litigation framework. ${ }^{117}$ A damage suit, requiring that a specific plaintiff show present concrete harm, can hardly take into account harm to nonspecific future populations. Finally, the specter of a damage award will not necessarily deter the hazardous activity, or even change the method of operation. The risk-creating entity is merely forced to make a tradeoff between the damage award in other cases, discounted by its probability, as against the benefits of continuing with the activity unchanged. The power of the compensatory tort lawsuit is thus too slow, too indirect, and too uncertain to provide a powerful decisionmaking device.

\section{b. Mediation-Negotiation}

Mediation-negotiation models entail voluntary participation by contesting parties who meet face-to-face in discussions with a third party, the mediator or arbitrator, to facilitate the resolution of disputes. In scientific mediation, ${ }^{118}$ technical experts representing different views would, with the assistance of a mediator, write a joint paper to explain areas of agreement and disagreement, each scientist's reasons for disagreement on each point, and further information needed before a decision can be made. It has similarities to the Science Court model in its quasi-adversarial presentation of opposing viewpoints, but with the me-

115 See Recombinant DNA Research Act of 1977: Hearings before the Subcommittee on Health and the Environment of the House Committee on Interstate and Foreign Commerce, 95th Cong:, 1st Sess. 86, 86-96 (1977) (comments of Prof. Hubbard).

${ }_{116}$ See, e.g., Sindell v. Abbott Laboratories, 85 Cal. App. 1, 149 Cal. Rptr. 138 (1978), rev'd, 26 Cal. 3d 588, 607 P.2d 924, 163 Gal. Rptr. 132 (1980), cert. denied, 449 U.S. 912 (1980). See generally Note, Market Share Liability: An Answer to the DES Causation Problem, 94 HaRv. L. Rev. 668 (1981).

117 See generally Furrow, Legislative and Judicial Remedies for Environmental Wrongs, 6 SUFFolK U.L. REv. 536 (1972).

${ }_{118}$ See Abrams, Nuclear Politics in Sweden, 21 EnviRonment 6 (1979). 
diator narrowing the issues with the consent of the parties rather than a panel of judges resolving the issue. Like the Science Court, it probably would not be useful until rather late in the development of a controversy. Moreover, adequate participation would be difficult to define or assess. Although the process could rely upon the input of those individuals and groups who care strongly enough to enter the negotiations, including laymen, government involvement would probably be necessary to set the process in motion. In addition, mediation works best when the protagonists share a common ground which might lead to a satisfactory compromise. In technological controversies, however, antagonist groups are ill-defined; they may not share the values necessary to resolve the dispute in the absence of a more coercive framework such as that provided by litigation, in which a decision, whether based upon concensus or not, must be reached.

\section{c. Decision Boards}

A "decision board" concept has been offered by Ramo as part of his overall proposal, which includes the technological FBI discussed above. ${ }^{119}$ Following an investigation, various boards would be appointed by the President as needed. Congress, the President, or the investigatory agency could use the decision boards to resolve a question in areas of scientific uncertainty, and each would have its jurisdiction defined by Congress. It is hard to see how this differs from current agency structures, such as the Consumer Product Safety Commission, or what it adds to present agency regulation.

\section{Elitist Control Models}

Professional self-regulation can operate successfully in theory, but there are significant problems in practice, as noted above. ${ }^{120}$ This model builds upon scientists' capacity to investigate a problem area relying on their capacity to impose sanctions on those working in dangerous areas. ${ }^{121}$ The Asilomar Conference, at which recombinant DNA was discussed, is cited as one example of such self-governance. ${ }^{122}$ If the effectiveness of self-regulation in other professions such as medicine is any guide, however, the regulation is likely to be limited to spotting the incompetent or dishonest practitioner and forcing him out. ${ }^{123}$ Actual

110 See supra note 95 and accompanying text.

120 See supra text accompanying notes 34-41.

121 See id.

122 See infra note 148.

123 For a general discussion of self-regulation in the medical profession, and its 
cessation of a hot line of research or self-imposition of controls is unlikely given the infractions that have occurred under the NIH Guidelines governing recombinant DNA research.

Public control over funds is considered sufficient by most scientists to control problems of research. Government funding controls provide a lever for compelling disclosure of the details of research and the imposition of conditions upon its conduct. ${ }^{124}$ The problem with relying on such an approach as a means of control of the risks of a new line of research is twofold. First, the decisionmakers in the agency assigned the function of deciding on allocation of monies are often either former researchers themselves or program directors who must rely on peer review, raising questions of bias and conflict of interest. ${ }^{125}$ If the researcher promises exciting new advances within the scope of the funding agency's mandate, then the agency will also benefit from successes in the research through continued congressional funding. The pressure is toward encouraging research which is "good" science, even though it may be risky science. In fact, the exercise of the power to cut off funds or to impose sanctions for the violation of agency guidelines has only rarely been exercised. ${ }^{126}$ Second, research by private industry is not affected by government funding restrictions. Current evidence suggests that in the swift move to exploit commercial applications of biological technologies, new companies have violated a number of safety guidelines. ${ }^{127}$

Agency regulation of technological hazards is the most familiar and best developed regulatory model, offering a rich variety of regula-

limitations, see E. Freidson, supra note 43.

124 See Robertson, supra note 61 , at $506-08$, for a discussion of state-imposed limitations as a condition of funding.

125 An example of the failure of peer review mechanisms to prevent an accident is the smallpox death in Bedson's laboratory in Birmingham, England. As Wade Hawkes noted, "the system appears to have connived at breaches of the most elementary kind in laboratory security simply because Bedson was a well-known figure. . . " Hawkes, Sinallpox Death in Britain Challenges Presumption of Laboratory Safety, 203 Scr. 855 (1979).

${ }^{126}$ See supra note 124.

127 An inspection of Genentech's recombinant DNA facilities in April, 1980, revealed major safety problems, including use of glass instead of metal flasks. See Genentech Plant's Faults Attributed to Rapid Growth by NIOSH, 1 GENETIC ENG. LETTER 2, 3 (1981). The defects fly in the face of the conventional notions that large scale applications are safer than laboratory work or at least no more risky. See Gordon, Hazards of Making the Same Product by Recombinant DNA as Compared to Other Methods, 3 Recombinant DNA Bulz. 209 (1980). Gordon concluded: "Containment and other safety procedures have long been standard for both fermentation and petrochemical processes, on a plant scale. Accidents are extremely rare if established protocols are followed. However, if the remotely possible happens (e.g., failure of automatic controls, rupture of metal reaction vessels, etc.) catastrophe can result." Id. at 211. 
tory control devices ${ }^{128}$ within a framework of ongoing staff analysis and funding for the investigation and monitoring of problems. The assumption of most commentators is that creation of a new regulatory body, or expanding the powers of an existing one, offers the optimal means of controlling novel hazards in areas of uncertainty. ${ }^{129}$ Legislatures, however, as the history of congressional involvement in the recombinant DNA controversy indicates, are subject to a range of problems when contemplating such complex regulatory tasks. They are typically reluctant to innovate except where public pressure is strong. ${ }^{130}$ They are poorly equipped to obtain, understand, and use current scientific information. ${ }^{131}$ They may enact inappropriate legislation, based upon regulatory models that do not suit the risks at issue. ${ }^{132}$ Most important, as the recombinant DNA case illustrates, they may choose not to act, in

128 See generally Breyer, Analyzing Regulatory Failure Mismatches, Less Restrictive Altermatives, and Reform, 92 HARv. L. REv. 547 (1979); Cranston, Reform Through Legislation: The Dimension of Legislative Technique, 73 Nw. L. REv. 873 (1978); Stewart, Regulation, Innovation, and Administrative Law: A Conceptual Framework, 69 CALIF. L. REv. 1256, 1263-77 (1981).

${ }_{129}$ See, e.g., Note, Rethinking Regulation: Negotiation as an Alternative: to Traditional Rulemaking, 94 HARv. L. REv. 1871, 1874-75 (1981). The Environmental Protection Agency (EPA) is currently moving to regulate products of genetic engineering, such as pesticides produced by genetic engineering techniques. Given uncertain legislative authority for such regulation, however, manufacturers are likely to litigate EPA's authority. Sun, EPA Revs Up to Regulate Biotechnology, 222 Scr. 823 (1983). A recent legal analysis of current federal agency authority to regulate genetic technologies has concluded that while the various statutes probably give the EPA authority to acquire information as to risks of industrial use of genetic engineering technologies, the best solution would be a new statute specifically addressing the new genetic technologies. See McGarity \& Bayer, Federal Regulation of Emerging Genetic Technologies, 36 VAND. L. REV. 461, 537-39 (1983). The authors conclude:

EPA, OSHA, and FDA have a wide array of regulatory authorities available to address those potential dangers. A court, however, may limit EPA's authority by determining that the genetically altered DNA in a mirco-organism is not a chemical substance. To ensure against this possibility, Congress could amend the TSCA to give EPA explicit authority to address the infective risks of new biotechnologies. Congress also should appropriate to the relevant agencies adequate resources to implement their data gathering and risk assessment functions. Without monetary and personnel resources, the regulatory agencies simply will not accomplish these important objectives, and they will have lost the opportunity to oversee the unfolding of the dramatic new genetic engineering technologies.

Id. at 540 .

130 See Dienes, Judges Legislators, and Social Change, 13 AM. BeHav. ScrenTIST 511 (1970).

191 See Yellin, supra note 4, at 551.

132 Consider, for example, Senator Kennedy's proposed legislation regulating recombinant DNA, incorporating an OSHA-style inspection system, coupled with licensing. See Recombinant DNA Safety Regulation Act, S. 1217, 95th Cong., 1st Sess. § 3 (1977). For criticism, see Szybalski, Much Ado About Recombinant DNA Regulations, in Biomedical Scientists and Public Policy 97 (H. Fudenberg \& V. Melnick eds. 1978). 
the face of complex issues and forceful lobbying by the affected interest groups. ${ }^{133}$ The creation of a new government agency dedicated to policing scientific research, not just for laboratory safety but for control over uncertain risks, is not an attractive proposition, either to the scientific community or to critics of the costs and inefficiencies of federal regulation.

Even assuming Congress could enact an appropriate, comprehensive administrative scheme, however, problems would remain. Agencies tend to have a highly focused perspective and set of biases. One does not have to accept the notion of agency "capture" wholeheartedly to be uncomfortable with agencies like NIH handling the drafting and promulgation of regulations for scientific research. ${ }^{134}$ An agency committed to an important scientific and technological goal cannot be expected to strike the proper balance between safety and progress. Support and promotion of the research by an agency leads inevitably to "the vesting of professional, as well as of economic, interests in the application and exploitation of that technology."135 A new regulatory framework, even if it could pass muster in the current political climate, carries with it the biases and rigidities that inevitably accompany a new bureaucracy devoted to policing a particular technology.

\section{The Public Control Model}

Use of negotiated rules has been suggested as a means of ensuring interest representation, relying on the views of parties directly affected by the potential rules of an agency. As the advocate of such a model contends, "if negotiators effectively represent all interests, negotiation should make the administrative process more democratic while enhancing regulatory efficiency. By inviting affected groups to negotiate rules, the agency would create a social microcosm, replicating the interest balancing process that underlies current rulemaking procedures."136 A novel and promising suggestion, it presumes an existing agency structure, and its sole reform goal is to enhance the representational nature of that agency's decisionmaking.

133 See L. Cavalieri, supra note 74, at 110-27.

134 See Chargaff, On the Dangers of Genetic Meddling, 192 Scr. 939 (1976).

1ss Bereano, Recombinant DNA: Issues on the Regulation of Basic Scientific Research, 20 IDEA 315, 322 (1981).

${ }^{136}$ Note, Rethinking Regulation: Negotiations as an Alternative to Traditional Rulemaking, 94 HARV. L. REv. 1871, 1874-75 (1981). 


\section{The Elitist Judicial Oversight Model}

Federal court oversight of agency decisionmaking provides what can be viewed as a separate model. Such processes of judicial review vary depending upon the congressional mandate given to the particular agency whose regulations are under scrutiny. In the environmental area, the "hard look" doctrine ${ }^{\mathbf{1 3 7}}$ has led courts persistently to demand reasoned decisionmaking by administrative agencies in which an agency discloses information gaps, value choices, and assumptions. An agency also may be compelled to undertake further effort to address weaknesses, as by gathering further data on a central issue. Critics of judicial review of complex scientific controversies have pointed out that courts are ill-equipped to conduct such review. A significant number of judicial errors are evident, for example, in nuclear power review cases. ${ }^{138}$ One critic, Joel Yellin, has proposed a committee of standing masters, a high technology review panel, to assist courts reviewing agency decisions in areas of technological complexity, such as in environmental and energy matters - "a body within the judiciary specially constructed to provide reasoned second opinions responsive to the special nature of modern environmental issues."139 Federal courts could refer complex questions to the standing masters, a committee of scientists, engineers and lawyers. Yellin's proposal, drawn from the lessons and failures of nuclear power regulation, involves a two-step process. In the first step, the judge requests from the masters information on technical issues. The masters would make findings, which would then be reviewed by the court. The second step is "designed to elicit the broader societal implications of proposed technological programs or regulation."140 Unresolved questions apparent on the administrative record would be examined in light of the scientific and engineering literature, and members of the professional communities would be invited for consultation. Yellin's goal is to set up a dialogue between the scientific community and the courts, by which a body of knowledge will develop in complex issues to help courts resolve environmental controversies.

A committee of standing masters, as an adjunct to courts reviewing agency decisionmaking in areas of scientific controversy, would provide

137 The phrase "hard look" originated with Judge Leventhal in Greater Boston Television Corp. v. Fed. Communications Comm'n, 444 F. 2d 841 (D.C. Cir. 1969), cert. denied, 403 U.S. 923 (1971). For an analytical discussion, see Rodgers, A Hard Look at Vermont Yankee: Environmental Law Under Close Scrutiny, 67 GEo. L.J. 699, 705-09 (1979).

138 See id.

139 Yellin, supra note 4 , at 554.

140 Id. at 556. 
a valuable reform. Like the negotiated-rules model, however, Yellin's proposal cannot solve the problems with which this article is concerned, because it presupposes the existence of an agency with the jurisdiction, and the capacity, to control novel, emerging hazards.

\section{Conclusion}

None of the models discussed above is ideally suited for a new hazard in an area of uncertainty, nor are the more effective possibilities likely to come into being in the foreseeable future. A public nuisance model, drawing upon existing norms and legal rules, may best serve the function of both technology-assessment and technology-governance. Considering the four goals by which institutional mechanisms must be measured-checking momentum, counteracting bias, generating information, and promoting public participation-a private litigation model provides the best prospects for investigating new hazards, resolving questions of the extent of the harm posed, and controlling the conduct of the research.

\section{Public Risks and Private Rights: Reviving the Common Law of Nuisance Entitlements}

The choice of means for governing novel hazards arising out of scientific research requires a complex comparison of the relative strengths of alternative regulatory models. The assumption of most commentators has been that a new regulatory body offers the optimal solution. There is little reason to believe, however, that Congress could act to regulate research hazards effectively. On the other hand, there are many reasons to believe that a private law model can fill the present regulatory vacuum.

A private law model can draw on established norms-entitlements to be free from "dread," or-fear of catastrophic outcomes. A court's consideration of a problem, and articulation of applicable private norms, may change social perceptions of the problem's nature and seriousness. The equitable powers available to a judge superintending complex public actions provide the possibility of flexible remedies, after the threshold issue of the violation of a legally cognizable right has been found. These powers allow circumvention of the objection in private litigation that an unconditional injunction does too much, too fast; they draw upon a tradition in tort law which recognizes the value of conditional injunctions and flexible supervisory controls over hazardous activities, upon an emerging consensus on the range of powers available to the trial judge, and upon a recognition that a process of negotiation 
is occurring. The judiciary has a comparative advantage over other institutions, existing and proposed, given the goals which technology assessment seeks to achieve. Judicial intervention in new hazards of research is analogous to administrative licensing, where potential danger is often cited as justification for licensing activities as diverse as nuclear installations and medical devices. ${ }^{141}$ Private litigation can be a form of prior approval required of an activity which is novel and not yet subject to government regulation. The relative freedom of the courts from short-term political pressures gives them a unique perspective from which to gauge the long-term risks and implications of major new developments, ${ }^{142}$ without the unique problems associated with administrative agencies. ${ }^{143}$

Nuisance law recently has undergone a minor renaissance in environmental law. Federal courts have acknowledged the existence of a federal common law of nuisance which can be invoked by a private litigant. ${ }^{144}$ Commentators have advocated further development of the common law of nuisance at both the state and federal levels to bring standards for the issuance of injunctions into line with analogous legislation governing areas such as toxic substances. ${ }^{145}$ Private nuisance actions have been conceded to have an important residual role in environmental land-use decisionmaking, ${ }^{146}$ as reflected in liberalized standing

141 See Cranston, supra note 128, at 901.

142 See Wellington, Comnon Law Rules and Constitutional Double Standards: Some Notes on Adjudication, 83 YALE L.J. 221, 248 (1973).

143 See Casper, Technology Policy and Democracy, 194 Scr. 29 (1976).

144 See, e.g., National Sea Clammers Ass'n v. City of New York, 616 F.2d 1222 (3d Cir. 1980), holding that the common law nuisance remedy recognized in Illinois v. City of Milwaukee, 406 U.S. 91 (1972) would apply, recognizing the Restatement of Torts formulation of a public nuisance as an appropriate source for the federal rule. However, in City of Milwaukee v. Illinois, 451 U.S. 304 (1981), the Supreme Court held that the Federal Water Pollution Act Amendments of 1972 displaced federal common law, severely restricting the extent to which private rights can be derived from federal statutes. While a body of federal common law still exists, it cannot be expanded to effectuate federal interests absent a clear expression of Congressional intent in the statute from which the alleged federal right is claimed. See, e.g., Transamerica Mortgage Advisors, Inc. v. Lewis, 444 U.S. 11 (1979); Touche Ross \& Co. v. Redington, 442 U.S. 560 (1979). The Supreme Court has in effect created a presumption against judicial recognition of private rights, so that it is unlikely that the federal common law of nuisance can be expanded based on federal legislation dealing with the environment or other areas.

${ }^{145}$ See Note, Allocating the Costs of Hazardous Waste Disposal, 94 HaRv. L. REv. 584, 593-96 (1981).

${ }_{140}$ See Developments in the Law-Zoning, 91 Harv. L. Rev. 1427, 1585 (1978); see also Bryson \& Macbeath, Public Nuisance, the Restatement (Second) of Torts, and Environinental Law, 2 Ecology L.Q. 241 (1972); Grad \& Rorkett, Environmental Litigation-Where the Action Is?, 10 NAT. Resources J. 742 (1970); McLaren, The Common Law Nuisance Action and the Environmental Battle: Well-Tempered Swords or Broken Reeds?, 10 Osgoode Hall L.J. 505 (1972); Schuck, Air Pollution as a 
requirements allowing a private party to sue to vindicate public rights. ${ }^{147}$ The criticisms leveled against reliance upon a common law nuisance model for more than interstitial gap-filling are fundamentally criticisms of the limitations of a court, or of the adversary system, in responding to certain classes of problems. For reasons discussed in the previous section, however, such criticisms do not apply to the problem of technology assessment and control.

\section{A. The Nature of Nuisance}

Nuisance law has suffered from neglect in the area of technological risk. It has come to be viewed as little more than a historical source of ideas useful in establishing administrative risk-assessment procedures, a way station on the path to public regulation. ${ }^{148}$ Nuisance law goes back to medieval English law which as early as the sixteenth century recognized the desirability of specific relief against nuisances, often those presenting public health problems. The English writs spoke of "filthinesses which are in the ways and lanes of the said city and the suburbs thereof, the air there is so much corrupted and infected, that a dreadful terror strikes the masters and scholars."149 The realm of the nuisance action, one historian noted, was the "stinking privy, the fouled or diverted stream, the polluting chimney."160 Historically, nuisance law provided a tool for relieving actual or threatened noxious uses of land in the vicinity of plaintiff landowners. ${ }^{101}$ It was a device for striking land-use bargains, a town-planning device ${ }^{\mathbf{1 5 2}}$ prior to the emergence of zoning laws. Before 1750, suits were often aimed at mismanagement of time-honored occupations, such as the giant piggery in the Boston

Private Nuisance, 3 Nat. Resources Law 475 (1970); Warren, Nuisance Law as an Environmental Tool, 7 WARE FoREST L. REV. 211 (1971).

147 See Jaffe, Standing to Sue in Conservation Suits, in Law and ENvironment 123 (U. Baldwin ed. 1970); see also state statutes such as Mich. CoMP. LAws ANN. $\$ \$ 691.1201-.1207$ (West Supp. 1982), which abolish traditional standing requirements and allow any citizen to sue, and which authorize judicial creation of a substantive common law of environmental quality. See generally infra note 233 and accompanying text.

148 See, e.g., Yellin, supra note 4, at 981-85.

140 Fitz-Herbert, New Natura Brevium, $185 \mathrm{D}$, Writs of Nuisance which are Vicontiel (Before 1537), quoted in Z. ChafEe, JR. \& E. RE, EquitY 716 5th ed., 1967.

150 Brenner, Nuisance Law and the Industrial Revolution, 3 J. LEG. STUD. 403, 403 (1974).

151 See, e.g., Annot., 90 A.L.R. 1207 (1934) (industrial plant); 86 A.L.R. 998 (1933) (bakery); Annot., 50 A.L.R. 107 (1927) (garage); Annot., 48 A.L.R. 518 (1927) (pesthouse); Annot., 33 A.L.R. 725 (1924) (amusement park). See generally Ellickson, Alternatives to Zoning: Covenants, Nuisance Rules, and Fines as Land Use Controls, 40 U. CHI. L. REv. 681 (1973).

${ }^{182}$ See Ellickson, supra note 151. 
suburbs producing a smell like "the odor of one pig multiplied five hundred times."163 During the last two centuries, nuisance cases in both England and America arose during transitional stages between older community arrangements and emerging industries. The industrial revolution spawned nuisance litigation by farmers and homeowners on the troubled frontier of new technologies against textile mills, blast furnaces, hydraulic mines, and cement plants. ${ }^{154}$ Nuisance law was also used to control "immoral" uses such as movie theatres. ${ }^{165}$ It was a means of restricting "upsetting" institutions, such as tuberculosis santoriums, which created a sense of unease among neighbors, ${ }^{186}$ and it restricted the operation of potentially catastrophic activities, such as the storage or use of explosive materials, even when the probability of harm was slight. ${ }^{168}$

Nuisances are classified as public or private. ${ }^{168}$ A private nuisance was early defined as an annoyance that interferes with the ability of another to use or enjoy his land, ${ }^{169}$ with depreciation in the value of the property the measure of present damages. ${ }^{160}$ The concept of legal injury expanded beyond the traditional injury to property as it became apparent to the courts that some losses could not be stated in terms of market value. ${ }^{161}$ In nuisance law, as in other areas of law, the concept of injury came to encompass not only harm to ownership interest, but also to state of mind. ${ }^{162}$ Thus, a nuisance may cause interference by

158 Commonwealth v. Perry, 139 Mass. 198, 200, 29 N.E. 656 (1885) (words not reported in unofficial reporter).

164 See Z. CHAFEE AND E. RE, supra note 149, at 769 n.69 (list of activities which the plaintiff sought to enjoin included barking dogs, popcorn stands, supermarkets, backyard barbecues, prefabricated houses, and libraries in residential areas).

${ }^{185}$ For a thorough discussion, see Rendleman, Civilizing Pornography: The Case for An Exclusive Obscenity Nuisance Statute, 44 U. CHI. L. REV. 509 (1977).

${ }_{158}$ See, e.g.,. Statler v. Rochelle, 83 Kan. 86, 109 P. 998 (1910); Brink v. Shepard, 215 Mich. 390, 184 N.W. 404 (1921); Birchard v. Board of Health, 204 Mich. 284, 169 N.W. 901 (1918); Everett v. Paschall, 61 Wash. 47, 111 P. 879 (1910).

${ }^{157}$ Cumberland Torpedo Co. v. Gaines, 201 Ky. 88, 255 S.W. 1046 (1923); Whittemore v. Baxter Laundry Co., 181 Mich. 564, 148 N.W. 437 (1914).

${ }_{158}$ See generally Prosser, Private Action for Public Nuisance, 52 VA. L. REv. 997, 997-99 (1966).

159 Id. (1973).

160 See generally D. Dobbs, Handbook on the Law of Remedies 332-35

161 See, e.g., Kenyon v. Gity of Chicopee, 320 Mass. 528, 70 N.E. 2d 241 (1946). See generally W. Prosser, LAW OF TORTS 591-93 (4th ed. 1971); J. VinING, Legal Identity: The Coming of Age of Public Law 32 (1978); Sax, Takings, Private Property and Public Rights, 81 YALE L.J. 149 (1979); Developments in the Law-Injunctions, 78 HARv. L. REv. 994, 998-1001 (1965)..

162 Some nuisance decisions specifically acknowledged that mental disturbance or psychic injuries caused by a private or public nuisance might be actionable at law or equity, most clearly in cases involving funeral parlors or crematoriums. See, e.g., State v. Feezell, 218 Tenn. 17, 20, 400 S.W.2d 716, 719 (1966) ("We do not say that mental 
physically invading another person's land, but fear of future harm may also be sufficient to establish a nuisance. ${ }^{163}$

A public nuisance has been defined as an interference with "a right common to the general public."164 It affords recovery in damages to individual plaintiffs only if they suffer "special damages" different from those suffered by the general public. ${ }^{165}$ A showing of special damages may not be necessary, however, if the plaintiff seeks only injunctive relief and otherwise has standing to sue. ${ }^{168}$ Personal discomfort or

disturbances or "psychic" injuries caused by a nuisance, public or private, are not such as may be actionable at law or equity. They can, in fact, be very real to the complainants."). See also Annot. 39 A.L.R.2d 1000, 1001, 1022-26 (1965):

If an undertaking establishment in a purely residential section causes, from its normal operations, depressing feelings to families in the immediate neighborhood, and, as a constant reminder of death, appreciably impairs their happiness or weakens their powers of resistance and depreciates the value of their properties, such an establishment constitutes a nuisance.

Id. at 1001.

Anticipatory injunctions against fear-inducing activities became more difficult to obtain, however, as municipal zoning ordinances supplanted private remedies. The na: ture of the fear-producing institutions also changed. Half-way houses replaced sanitaria as the source of neighborhood anxiety, and courts began to reject fear or apprehension as the basis for recovery when based upon "speculation" that the residents of the halfway houses would commit criminal acts. One senses in these more recent cases a judicial hostility toward the prejudices which underlie such litigation. See, e.g., Nicholson v. Connecticut Half-Way House, Inc., 153 Conn. 507, 218 A.2d 383 (1966), in which the court denied relief to residents of a neighborhood in which a half-way house for inmates from the Connecticut State Prison were to be placed: "This present fear of what may happen in the future, although genuinely felt, rests completely on supposition. The anticipation by the plaintiffs of the possible consequences of the defendant's proposed use of the property can be characterized as a speculative and intangible fear." Id. at 511,218 A.2d at 386.

${ }^{163}$ See Harris Stanley Coal \& Land Co. v. Chesapeake \& O. Ry., 154 F.2d 450, 453-54 (6th Cir.) (enjoining prospective mining operation that might destabilize a cliff overhanging an active railroad track), cert. denied, 329 U.S. 761 (1946); Henderson v. Sullivan, 159 F. 46 (6th Cir. 1908) (partially enjoining dynamite storage); Tyner v. The People's Gas Co., 131 Ind. 408, 31 N.E. 61 (1892) (enjoining storage and use of nitrogylcerin in residential areas); Cheatham v. Shearon, 31 Tenn. (1 Swan) 213 (1851) (enjoining storage of gunpowder in city). See generally $58 \mathrm{AM}$. JuR. 2d Nuisances \& 147 (1971).

184 See ReStATEMENT (SECOND) OF ToRTs $§ 821 \mathrm{~B}(1)$ (1979).

188 Whether a plaintiff's damages must be of a distinctly different kind to satisfy the rule, or simply differ in degree, is still unclear. Prosser writes: "it is uniformly held that a private individual has no action for the invasion of the purely public right unless his damage is in some way to be distinguished from that sustained by other members of the general public." W. Prosser, supra note 61, at 586. Personal injury or harm to health, or mental distress, or any substantial interference with the plaintiff's use and enjoyment of his own land, has been enough to confer standing, since this makes the nuisance private as well as public. However, the courts often constricted this notion of "special injury" with a view to protecting industrial development. See generally Kurtz, Nineteenth Century Anti-Entrepreneurial Nuisance Injunctions-Avoiding the Chancellor, 17 WM. \& MARY L. REv. 621, 666-67 (1976).

${ }_{168}$ See Restatement (Second) of Torts $\& 821 \mathrm{C}$ (1979). 
illness may be sufficient to constitute special damages, ${ }^{167}$ and the effect can be on an occupant or possessor of property as well as the owner. Fear of future harm has been cited as one basis for standing to assert a public nuisance. ${ }^{168}$

Nuisance law had a hard edge in that it often afforded relief without any showing of negligence. Courts rejected defenses based upon compliance with a standard of care and community benefit. ${ }^{169}$ Nuisance law therefore might have played a powerful restraining role in the industrialization of both England and America. ${ }^{170}$ It did not have such a role, however, because of judicial sensitivity to economic development. ${ }^{171}$ Entrepreneurs avoided injunctive relief by means of judicial

${ }^{107}$ Riblet v. Spokane-Portland Cement Co., 45 Wash. 2d 346, 274 P.2d 574 (1954); Annot., 142 A.L.R. 1307 (1943).

${ }_{188}$ See Restatement (SECOND) OF ToRTS § 821B comment g (1979) ("thus the threat of communication of smallpox to a single person may be enough to constitute a public nuisance because of the possibility of an epidemic"); Duke Power Co. v. Carolina Environmental Study Group, 438 U.S. 59 (1978) ("personal stake" recognized where the dispute involved a speculative, long-term prediction of harm).

${ }^{109}$ See, e.g., McCleery v. Highland Boy Gold Mining Co., 140 F. 951,952 (D. Utah 1904).

270 See Brenner, supra note 163, at 403.

171 For a development of the thesis that judges altered nuisance law, as well as other substantive doctrines, in the direction of economic subsidization, see M. HoRwitz, The Transformation of American Law 1780-1860 (1977). Horwitz notes that while substantive tort doctrine remained plaintiff-oriented, "judges began to establish a variety of ingenious variations in its application that eventually transformed the substantive doctrine itself." Id. at 76. These doctrinal changes were distinctive in light of "the extent to which common law doctrines were transformed to create immunities from legal liability and thereby to provide substantial subsidies for those who undertook schemes of economic development." Id. at 99-100. But see Schwartz, Tort Law and the Economy in Nineteenth-Century America: A Reinterpretation, 90 YALE L.J. 1717 (1981).

The history of nuisance doctrine in England is traced in Brenner, supra note 163. Brenner notes that in the 1850's the law was invaded by a standard of care. It was applied differently to factories than to private individuals, however, and was hardly applied at all to quasi-public enterprises such as railways by reason of their statutory authorization; there was no systematic prosecution of public nuisances; and a decline in property values ceased to be sufficient proof-actual physical damage came to be required. "Damage to the occupier's health and comfort was no longer a property injury per se. Since property values in the most contaminated areas often rose rather than fell .. . unhealthy conditions were doubly excluded from the scope of a nuisance remedy." Id. at 420 .

The evolution of the American law of nuisance injunctions is traced in Kurtz, supra note 165 . Kurtz notes that since 1830 a range of procedural maxims and defenses were developed to counteract the plaintiff-oriented substantive law. Thus, a long and undisputed right must have been violated, requiring the plaintiff on occasion to sue at law, prior to moving to equity. Most importantly, only actual not prospective nuisances could be enjoined. If a few other land owners were affected by the same nuisance as the plaintiff, then the private nuisances could be aggregated into a public nuisance, and each would thereby lose standing to sue on a private nuisance theory. $\mathbf{A}$ negligence standard and an industrialization defense were added, along with a balancing test. From 1871 to 1916, courts applied the balancing test to determine injunctive 
immunities and defenses. ${ }^{172}$

\section{B. The Problem of Risk}

The problem of relief from the risk of harm is one of the most difficult issues in the law. Ordinarily, an actionable wrong occurs when a person has suffered injury to person or property. But the risks created by a bomb stored in an armory, or a laboratory engaging in research,

relief, weighing the probable effects on the plaintiff, the defendants, and the public. Because the expenditures of entrepreneurs were normally significant in plant and equipment, a balancing test operated like a presumption in favor of the defendant. Some courts then used the balancing test to determine whether a nuisance in fact existed, rather than merely to assess the applicability of injunctive relief.

A minority rejected the balancing test. See Whalen v. Union Bag and Paper Co., 208 N.Y. 1, 2, 101 N.E. 805, 806 (1913) ("although the damage to the plaintiff may be slight as compared with the defendant's expense of abating the condition, that is not a good reason for refusing an injunction"). Normally, however, public benefit was considered in light of the defendant's operation, the likely hardship the parties would suffer if the operation is or is not enjoined, and the equities between the parties, in terms of misconduct or bad faith. See, e.g., Smith v. Staso Milling Co., 18 F.2d 736 (2d Cir. 1927); Riter v. Keokuk Electro-Metals Co., 248 Iowa 710, 82 N.W.2d 151 (1957). See generally D. DoBBS, supra note 160 , at $357-58$ (1973). Whalen was restricted, or abandoned, in Boomer v. Atlantic Cement Co., 26 N.Y.2d 219, 257 N.E.2d 870, 309 N.Y.S.2d 312 (1970). The general position seems to be that hardships should be balanced.

172 Defenses against nuisance actions based on zoning, statutory authorizations, and other governmental actions have only a restricted operation. Thus it is clear that a zoning ordinance permitting an activity generally is not a defense. See D. DoBBS, supra note 160, at 363; Comment, Real Property-The Effect of Zoning Ordinances on the Law of Nuisance, 54 MrCH. L. REv. 266, 270-71 (1955). A minority rule bars an injunction, however, if the activity is authorized by a zoning ordinance. See $\mathbf{D}$. DoBBS, supra note 160, at 363; see also Bove v. Donner-Hanna Coke Corp. 236 App. Div. 37, 258 N.Y.S. 229 (1932), where both damage and injunction were denied because of a zoning authorization.

The notion of "legalized nuisance," a second defense, provided an immunity for an activity conducted within statutory limits. Thus, "[w]here the Legislature has authorized an act, such act cannot constitute a public nuisance although it would otherwise be such, so long as the terms of the authorization are not abused or exceeded." Borough of Collegeville v. Philadelphia Suburban Water Co., 377 Pa. 636, 655, 105 A.2d 722, 731 (1954). See also Mayor of Baltimore v. Fairfield Improvement Co, 87 Md. 352, 39 A. 1081 (1898). However, major interference cannot be authorized, Richards v. Washington Terminal Co. 233 U.S. 546 (1914); W. PROSSER, supra note 161, at 606-07. A license or statutory authorization does not carry with it protection for risks if a nuisance is created. Commerce Oil Ref. Corp. v. Miner, 281 F.2d 465 (1st Cir. 1960). Even if the authorization is liberally construed, it will not cover risks other than those to which it is addressed. Thus in Commonwealth v. Kidder, 107 Mass. 188 (1871), a statute allowing gasoline storage if appropriate fire precautions were taken did not immunize the activity from nuisance liability due to odors.

Compliance with government safety and health requirements by laboratory or industry is not a bar to an award of actual or punitive damages, although it may be some evidence of reasonable conduct in a suit based on negligence. $C f$. Silkwood v. KerrMcGee Corp., 667 F.2d 908 (10th Cir. 1981), rev'd, 104 S. Ct. 615 (1984) (compliance with government safety regulations for nuclear facility). 
do not fit such a pattern. What types of risks are so serious that they constitute a tort for which injunctive relief can be granted before a specific member of the public suffers injury to person or property? Criteria for deciding when a risk becomes actionable may be derived through an analysis of the various doctrinal bases of tort liability.

\section{Considerations of Risk in Tort and Equity}

Negligence is the standard of liability imposed on persons engaged in activities with respect to which a moderate level of risk is accepted. Thus, a clear spectrum of risks presented by the act of driving an automobile is assumed by the general public. One who drives at 100 miles per hour or fails to pay attention while driving, however, has deviated from a standard level of acceptable conduct and must bear the responsibility for any harm resulting from the unreasonable risk. ${ }^{\mathbf{1 7 3}}$

In nuisance actions it is not always necessary to prove negligence. Those engaged in "abnormally dangerous" activities are held strictly liable for the damage which results. ${ }^{174}$ Probability of harm is one element courts will consider when deciding whether an activity is abnormally dangerous. Many dangerous activities, however, do not present a strong probability of mishap, ${ }^{175}$ but rather a potentially catastrophic (1972).

173 See Fletcher, Fairness and Utility in Tort Theory, 85 Harv. L. Rev. 537, 548

174 The Restatement lists six factors relevant to the determination of an activity as abnormally dangerous:

a) existence of a high degree of risk of some harm to the person, land or

chattels of others;

b) likelihood that the harm that results from it will be great;

c) inability to eliminate the risk by the exercise of reasonable care;

d) extent to which the activity is not a matter of common usage;

e) inappropriateness of the activity to the place where it is carried on; and

f) extent to which its value to the community is outweighed by its danger-

ous attributes.

Restatement (Second) of Torts $§ 520$ (1977).

It has been noted that the application of these factors to a possible recombinant DNA injury is uncertain, and one commentator has proposed federal legislation to clarify this uncertainty. See Friedman, Health Hazards Associated With Recombinant DNA Technology: Should Congress Impose Liability Without Fault?, 51 S. CAL. L. REv. 1355 (1978). The term "abnormally dangerous" was substituted for the term "ultrahazardous" in the second Restatement. REstatement (SECOND) OF TORTS App. $\S \S 519,520$ (1981). An "ultrahazardous activity" was defined in the first Restatement as one which: "(a) necessarily involves a risk of serious harm to the person, land or chattels of others which cannot be eliminated by the exercise of the utmost care, and (b) is not a matter of common usage." Restatement of TorTs $\S 520$ (1934).

175 Harry Kalven has noted that "one suspects that the extra hazardous activities of the popular mind, like flying airplanes, using explosives, and utilizing nuclear energy are probably unusually safe because of the expertise with which they are handled." Kalven, Tort Law-Tort Watch, 34 J. AM. Trial LAw. 1, 43 (1972) (footnote 
consequence. Blasting, ${ }^{176}$ storing of munitions, ${ }^{177}$ damming large bodies of water, ${ }^{178}$ and transporting petroleum ${ }^{178}$ are among the activities which may not present a strong likelihood of harm but have been found to constitute nuisances. In such cases the courts are likely to focus on the nature of the possible consequences, rather than on the probability that injury to person or property will occur. ${ }^{180}$

At one time some courts would enjoin any activity found to be a nuisance, ${ }^{181}$ but today most courts will issue an injunction only after a specific finding that the social utility of the nuisance is outweighed by the injury it causes. ${ }^{182}$ Thus, activities to which strict liability attaches are two kinds. Some are "reasonable," in that we value the activity sufficiently so that we do not prohibit it, but rather insist on compensation for the resulting injuries. A smaller category, "unreasonable" activities, presents intolerable risks and is subject to injunction. ${ }^{183}$

Singling out a category of risks, the consequence of which are to be borne strictly by those who create them, has been justified in'two ways. George Fletcher postulates that the level of risk presented by activities that give rise to strict liability exceeds that level of risk which the parties have mutually-albeit tacitly-agreed to accept. Activities which impose grave hazards on a community stand out, creating "threats of harm that exceed the level of risk to which all members of

omitted).

${ }_{176}$ See Spano v. Perini Corp., 25 N.Y.2d 11, 250 N.E.2d 31 (1969); Gossett v.

Southern Ry. Co., 115 Tenn. 376, 89 S.W. 737 (1905).

177 See Heeg v. Licht, 80 N.Y. 579 (1880).

178 See Rylands v. Fletcher, 1868 L.R. 3, H.L. 330; W. Prosser, supra note 161, at $505-14$.

170 See Siegler v. Kuhlman, 81 Wash. 2d 448, 502 P.2d 1181 (1973).

180 See, e.g., Harris Stanley Coal \& Land Co. v. Chesapeake \& O. Ry., 154 F.2d 450, 453 (6th Gir.), cert. denied, 329 U.S. 761 (1946), in which the court declared:

It may be that ... disaster could occur only upon a concatenation of circumstances of not too great probability. . . It is common experience, however, that catastrophes occur at unexpected times and in unforeseen places. . . A court of equity will not gamble with human life, at whatever odds, and for loss of life there is no remedy that in an equitable sense is adequate.

181 See Whalen v. Union Bag \& Paper Co., 208 N.Y. 1, 101 N.E. 805 (1913).

${ }_{182}$ See Boomer v. Atlantic Cement Co., 26 N.Y.2d 219, 257 N.E.2d 870 (1970) (awarding damages but denying injunctive relief against cement plant). In addition, the plaintiff must show that adequate alternative legal remedies are not available, and that the injury to be avoided is irreparable. See, e.g., Mack v. Califano, 447 F. Supp. 668 (D.D.C. 1978) (denying injunctive relief against the conduct of recombinant DNA research at the government laboratory at Fort Detrick, Maryland); see also Commerce Oil Refinery Corp. v. Miner, 281 F.2d 465, 474 (1st Cir. 1969); W. Prosser, supra note 175, at 603-04; Developments in the Law-Injunctions, supra note 176, at 99698, 1001-06 \& 1013-14 (1965); Note, Imminent Irreparable Injury: A Need for Reform, 45 S. CAL. L. Rev. 1025, 1031-37 (1972).

183 See Fletcher, supra note 173. 
the community contribute in roughly equal shares."184 Such risks exceed those which one would reasonably expect to incur, "relative to the background of innocuous risks in the community."188 Thus, one is held strictly liable for the consequences of those activities which subject members of a community "to a risk to which they were unaccustomed and which they would not regard as a tolerable risk entailed by their way of life."188 Many activities, however, such as the normal operation of heavy industry, small businesses, and research laboratories, may at times impose a different kind and degree of risk than those regularly encountered by most individuals. We do not impose strict liability as a prima facie matter on all activities simply on the ground that the present risks differ from the normal, "innocuous" risks created by the majority of individuals living in a community. The theory seems more appropriate to an earlier time of less fluid community memberships and stronger norms of custom and tradition. ${ }^{187}$ Hazards could be more easily differentiated by comparison to standard community practices: the domestic dog compared to the pet lion, for example, or the automobile in 1905 to the carriage.

Guido Calabresi provides a different rationale. ${ }^{188}$ Strict liability guarantees vigilance in the reduction of risks ${ }^{189}$ by placing the burden on the party with the best access to information and the means to implement changes. Thus, persons in a position to reduce the risks that they create must assume the consequences of those risks. Only they can "be looked to for advances in safety technology or other adjustments that minimize accident costs."190 This justification has a sense of fairness about it, as well as economic merit.

A possible difficulty with this cost-avoidance theory is its crudeness. Since manufacturers, universities, and owners of sports arenas or ice skating rinks will almost always have better access to information than those affected, the theory seems to dictate that liability will always fall on the institution. Distinctions among categories of hazards are not

184 Id. at 547.

185 Id. at 549.

${ }^{188} I d$. at 545 .

187 As Fletcher admits, "the increased complexity and interdependence of modern society renders legal analysis based upon a concept of community that presupposes clear lines of membership, relatively little overlapping, and a fair degree of uniformity in the activities carried on, exceedingly difficult in many cases." Id. at $549 \mathrm{n} .46$ (citation omitted).

${ }_{188}$ G. Calabresi, supra note 114; Calabresi \& Hirschoff, Toward a Test for Strict Liability in Tort, 81 Yale L.J. 1055 (1972).

${ }^{189}$ Rodgers, Negligence Reconsidered: The Role of Rationality in Tort Theory, 54

S. CaL. L. REv. 1, 11 (1980).

190 R. Posner, Economic Analysis of Law 140 (2d ed. 1977). 
important, nor are the relationships of risks to those affected by them or to the community in which they are created; only the relative abilities of the parties to assess and alter risks are considered.

It may be that in some strict liability situations, such as the classic blasting example, both a normative theory of reciprocal risks and an economic theory of cost avoidance offer complementary explanations. ${ }^{101}$ In both the normative and the economic approaches, there is a notion of the relative ability of the parties to ascertain risks and protect against them. In a blasting case, for example, when a contractor selects blasting as a preferred means of excavation in a residential area, he has decided to promote his own goals at the expense of the neighborhood, thereby subjecting the residents to an unexpected level of hazard to which they would not have agreed and against which they can not easily take precautions. It can also be said that he is in the best position to assess such risks and should be held liable in order to be forced to consider safety in selecting his means of excavation.

The risks associated with activities for which injunctive relief is appropriate pose a problem for the principal justifications of strict liability. In these cases damage relief is typically inadequate because the harm has not yet materialized. The harm threatened may effect widespread social disruption, health problems, or often irreversible ecological damage. Neither the degree of precautions taken nor the remoteness of the harm is relevant. ${ }^{192}$ We can easily identify the owner of the nuisance as the cheaper cost-avoider as between the parties, yet a decision is made that strict liability is an inadequate means of regulation-that the risks aren't worth taking in their present form.

Philosophers have long searched for principles to justify coercive intervention by the state. A basic justification is to alleviate reasonable fears of members of a community. ${ }^{193}$ Different levels of intervention may address different types of fears. ${ }^{184}$ Assurance of compensation, for example, provides an adequate response to the threat that one's property may get damaged. The prospects of catastrophe or of assault by another give rise to a more pervasive kind of fear, one requiring a higher level of intervention. Such general fear, or dread, is not assuaged

102 Calabresi and Hirschoff, however, suggest that the normative theory is merely an approximation of the cost-avoidance analysis. See Calabresi \& Hirschoff, supra note 188, at 1079.

192 See supra notes $175-80$ and accompanying text.

193 This theory is developed in R. Nozick, ANARchy, State, and Utopia (1974). See also Drane \& Neal, On Moral Justifications for the Tort/Crime Distinction, 68 Cal. L. Rev. 398 (1980). 10.

104 R. Nozick, supra note 193, at 65-66; Dane \& Neal, supra note 193, at 409- 
by the compensation of the individual. Robert Nozick develops this distinction as a means of distinguishing between "private wrongs," for which compensation is adequate, and "public wrongs," which must be prohibited. ${ }^{195} \mathrm{He}$ writes: "Thus the prohibition against fear-producing acts is not addressed to the fear of a person who is actually injured. That fear could be compensated. Rather, it seeks to protect the other members of society from the fear that they will suffer if such actions are allowed subject to the requirements of compensation." It is in part the individual's knowledge that the state allows such acts that causes the fear. Although Nozick contrasts damages in tort only with criminal sanctions, his argument applies equally to the problem of unreasonable risks. Public dread is increasingly the by-product of new, highly sophisticated research activities, partially as a reaction to the uncertain nature of the risks, and partially because the known possibilities include irreversible, intergenerational catastrophe. ${ }^{107}$

The concept of dread has served to define the boundaries of nuisance law. It has been used in cases involving activities which subject neighbors to a fear of harm transcending concerns over diminution of property values. In Everett $v$. Paschall, ${ }^{108}$ the plaintiffs sought injunctive relief against a tuberculosis sanitarium. Tuberculosis at this time was the cause of one-seventh of the deaths in the United States and was therefore widely feared, although scientists testified that it was not contagious beyond three feet when proper public health measures were followed. ${ }^{199}$ The plaintiffs' property values were shown to have been reduced by one-third to one-half by the presence of the sanitarium and the resulting fear on the part of the neighborhood. The court focused on the role of fear in nuisance cases:

If dread of the disease and fear induced by the proximity of the sanitarium, in fact, disturb the comfortable enjoyment of the property of the appellants, we question our right to say that the fear is unfounded or unreasonable, when it is shared by the whole public to such an extent that property values are diminished. The question is, not whether the fear is founded in science, but whether it exists; not whether it is imaginary, but whether it is real, in that it affects the move-

105 R. Nozick, supra note 193, at 67.

196 Id.

107 See Slovic, Fischhoff \& Lichtenstein, Facts and Fears: Understanding Perceived Risk, in Societal Risk Assessment: How SAfe Is SAfE Enough? (R. Schwing \& W. Albers eds. 1980).

10861 Wash. 47, 111 P. 879 (1910).

$190 \mathrm{Id}$. at $48,111 \mathrm{P}$. at 880. 
ments and conduct of men. Such fears are actual, and must be recognized by the courts as other emotions of the human mind. ${ }^{200}$

The court further noted that public health measures were required to ensure against contagion of tuberculosis, and "aside from the general dread of the disease . . . it is also known that the security of the public depends upon proper precautions and sanitation, which may at any time be relaxed by incautious nurses or ignorant patients."201 The court remanded the case and ordered injunctive relief granted. In Everett $v$. Paschall, the dread was not unreasonable, for scientific testimony indicated a risk of contagion. ${ }^{202}$ It simply was impossible to compensate someone for the fear resulting from this uncertainty, ${ }^{203}$ and the court

$200 \mathrm{Id}$. at $50-51,111 \mathrm{P}$. at 882 .

$201 \mathrm{Id}$. at $52-53,111 \mathrm{P}$. at 883.

202 The courts split over the issue of whether injunctive relief is available against hospitals treating diseases whose communicability is uncertain. In Stotler v. Rochelle, 83 Kan. 86, 109 P. 788 (1910), the court enjoined the construction of a cancer hospital in a residential neighborhood. Contradictory evidence had been presented on the question of communicability. The court concluded:

In the present state of accurate knowledge on the subject, it is quite within bounds to say that, whether or not there is actual danger of the transmission of the disease under the conditions stated, the fear of it is not entirely unreasonable. ...

The question is not whether the establishment of the hospital would place the occupants of the adjacent dwellings in actual danger of infection, but whether they would have reasonable ground to fear such a result, and whether, in view of the general dread inspired by the disease, the reasonable enjoyment of their property would not be materially interfered with by the bringing together of a considerable number of cancer patients in this place. However carefully the hospital might be conducted, and however worthy the institution might be, its mere presence, which would necessarily be manifested in various ways, would make the neighborhood less desirable for residence purposes, not to the oversensitive alone, but to persons of normal sensibilities.

Id. at 91-92, 109 P. at 793. See also Birchard v. Board of Health of City of Lansing, 204 Mich. 284, 169 N.W. 901 (1918) (enjoining public hospital for treatment of infectious disease as a nuisance, based on neighbors' fear).

In Cook v. City of Fall River, 239 Mass. 90, 131 N.E. 346 (1921), the court refused to enjoin a tuberculosis hospital as a nuisance since "it is not to be assumed in advance that such a hospital, well equipped and managed under the supervision of public health boards, will be a nuisance. Whatever danger of infection there may be will be no greater to [this] neighborhood . . . than [to another]." Id. at 93, 131 N.E. at 345 .

${ }^{203}$ The concept of dread became a central issue in litigation over the Three Mile Island nuclear failure. In People Against Nuclear Energy v. United States Nuclear Regulatory Comm., 678 F.2d 222 (D.C. Cir. 1982), rev'd, 103 S. Ct. 1556 (1983), the United States Court of Appeals for the D.C. Circuit held that in determining whether the nuclear power plant at Three Mile Island should be restarted, the psychological health and well-being of the community must be considered under the National Environmental Policy Act (NEPA), 42 U.S.C. $\$ \S 4321-4361$ (1976), in connection with an 
acted accordingly.

\section{The Elements of Risk}

Risk has two components: the severity of threatened harm, and the probability of its occurrence. ${ }^{204}$ In evaluating various ways of reducing risk, the potential harm must first be identified, and then its probability estimated. These steps comprise the expected utility model for rational decisionmaking, adopted by Learned Hand for the purpose of defining negligent conduct. ${ }^{205}$ Hand compared risk (R), which he defined as the product of the probability and the severity of threatened harm $(P \times S)$, with the cost of avoiding the hazard (c). When faced with a choice, the rational decisionmaker will prefer the prospect that offers the lowest costs or the highest expected utility. Refinements of this formula provide the basis for much government decisionmaking, with modifications to include second order consequences such as the effect of precautions on a consumer product market. ${ }^{208}$

\section{a. Limits in Determining Probability}

Probabilities pose a complicated problem of assessment because they may be subjective as well as objective. Objective probabilities are

Environmental Impact Statement. "NEPA does not encompass mere dissatisfactions arising from social opinions, economic concerns, or political disagreements with agency policies. It does apply to post-traumatic anxieties, accompanied by physical effects and caused by fears of recurring catastrophe." Id. at 230. The concerns of the lower court echoed the earlier refrains of the nuisance cases in recognizing the special status of individual and community dread in the face of potentially catastrophic events.

The United States Supreme Court then reversed the D.C. Circuit in a unanimous decision based upon the Court's reading of "environmental" in NEPA as applying only to the physical environment. Justice Rehnquist, writing for the Court, concluded: "But a risk of an accident is not an effect on the physical environment." $103 \mathrm{~S}$. Ct. at 1556. Given the kind of psychological evidence that the Nuclear Regulatory Commission would have had to generate and evaluate in order to determine impact, the Supreme Court was obviously worried about the strain on the NRC's limited resources. "The available resources may be spread so thin that agencies are unable adequately to pursue protection of the physical environment and natural resources." Id. The Supreme Court's concerns are clearly inappropriate, since the disaster at Three Mile Island is uniquely traumatic, and it is unlikely that regulatory agencies will regularly be confronted with such novel events. The conceptual validity of the inclusion of psychological stress, of "dread," within the meaning of NEPA, remains convincing.

${ }_{204}$ See generally W. Rowe, AN ANATOMY of Risk (1977).

205 United States v. Carroll Towing Co., 159 F.2d 169, 173 (2d Cir. 1947).

208 The Consumer Product Safety Commission, for example, undertakes in regulating hazardous consumer products to evaluate the nature and severity of the risk, the efficacy of a proposed standard in reducing the severity or frequency of injury, and the effect of the standard on the utility, cost, or availability of the product. This approach appears to follow from the language of the court in Aqua Slide ' $N$ ' Dive Corp. $v$. Consumer Product Safety Comm., 569 F.2d 831 (5th Cir. 1978). 
those we can determine using direct empirical evidence. If we want to know how likely it is that a specific weakened host E. coli strain of bacteria can survive passage through the human intestine, we can create the necessary circumstances to conduct a test. ${ }^{207}$ The probability of a concatenation of events leading to a disaster, on the other hand, cannot be estimated through experiments. Similarly, the putative benefits of an activity, such as the prospects of finding a cure for cancer posed by a line of research, cannot be gathered from empirical testing. "Subjective" probabilities must be assigned in such a case. But whose subjective probabilities ought to be used in making the decision? Experts in the area are an obvious choice, but expertise may blend with biases in favor of the activity under consideration. ${ }^{208}$ The choice of probabilities inevitably reflects a political as well as an expert viewpoint. ${ }^{209} \mathrm{~A}$ second problem in assigning probabilities arises when we find it difficult to conceptualize the possible consequences. Where the hazards are new, they may be only dimly perceived. The hazards of rare events may be ignored simply because they are difficult to imagine or do not come to mind. ${ }^{210}$ The very novelty of a new hazard denies us readily available analogies, which can result in complacency. A state of overconfidence

${ }^{307}$ Stich, The Recombinant DNA Debate: Some Philosophical Considerations in The Recombinant DNA Debate 191 (D. Jackson \& S. Stich eds. 1979).

${ }^{208}$ See supra notes 44-57 and accompanying text.

${ }^{209}$ In Holliday, Should Genetic Engineers Be Contained?, 73 New Scr. 399 (1977) subjective assessments are assigned to the variables needed to culminate in a range of catastrophic consequences including various epidemics and death by cancer. By assigning each variable an independent probability and then multiplying them, a small cumulative probability for an accident was derived. Holliday wrote: "[t]he cumulative values above represent extraordinary small probabilities. Thus, if 10 scientists in each of 100 laboratories carried out 100 experiments per year, the least serious accident . . . would occur on average once in a million years." Id. at 401 .

Others have disputed his assignments of probabilities, which Holliday admitted were subjective. A fundamental criticism is that he ignored other pathways with higher probabilities of outcome. In a paper criticizing Holliday's analysis, a scientist in the nuclear power industry wrote:

If we were proponents of Recombinant DNA research and wished to assess negative outcomes most favorably to the continuance of such research, what should our assessment strategy be? Perhaps a most effective strategy would be to assume mechanisms with a large number of causal steps and then to argue for low probabilities in as many as those steps as possible. We should be stubbornly blind to any choice of mechanism which might substantially reduce the size of the causal chain or increase any of the individual probabilities.

S. Mackey, A Critique of Arguments Against Regulation of Recombinant DNA Research (Spring, 1979) (unpublished manuscript on file with author). See also Kasper, Perceptions of Risk and Their Effects on Decisionmaking in SocIETAL RISK AssessMENT 76 (R. Schwing \& W. Albers eds. 1980).

${ }^{210}$ See Slovic, Fischhoff \& Lichtenstein, supra note 197, at 181; Tversky \& Kahneman, Judgment under Uncertainty: Heuristics and Biases, 185 ScI. 1124 (1974). 
often exists, preventing an awareness that additional information is needed. We may therefore tend to underestimate the likelihood of events which are hard to imagine, or which are outside of or remote from our normal experience. ${ }^{211}$ In evaluating the hazards of complex systems, the probabilities of failure are often underestimated, as the incident at Three Mile Island amply demonstrates. ${ }^{212}$

Two additional psychological processes further tend to limit our ability to assess the probability of outcomes. When communication about a risk reaches a certain saturation point through media coverage the individual will minimize or ignore the risk. Even though the problem remains, risk-aversion on an individual level may cease or may shift toward a position of neutrality as a defense against the tension. ${ }^{213}$ A second psychological tendency, cognitive dissonance, ${ }^{214}$ would affect the judgment of those responsible for a risk-creating activity. Individual researchers may attempt after a time to minimize internal conflict about the hazards of their research by rationalizing questionable decisions already made. As they commit themselves more deeply, they will be motivated to believe that they have made the right choice.

\section{b. Limits in Identifying Consequences}

Given the difficulty in assigning probability values, the complaint is often heard that the public tends to focus unduly on disastrous consequences. ${ }^{216}$ Such an emphasis is not irrational; it can be found in a line of nuisance law decisions. ${ }^{216}$ The identification of possible consequences does, however, pose serious problems for decisional theory. ${ }^{\mathbf{2 1 7}}$

First, the calculation of the gravity of harm, measured by the

211 See Kahneman \& Tversky, Prospect Theory: An Analysis of Decision Under Risk, 47 Econometrica 263 (1979); Slovic, The Psychology of Protective Behavior, 10 J. SafeTy Research 58 (1978); Slovic, Fischhoff \& Lichtenstein, Cognitive Processes and Societal Risk Taking, in Cognition and Social Behavior 165 (J. Carroll \& J. Payne eds. 1976).

${ }^{212}$ See generally The Three Mile Island Nuclear Accident: Lessons and Implications (T. Moss \& D. Sills eds. 1981), especially Jaffe, Technical Aspects and Chronology of the Three Mile Island Accident, at 37.

213 This phenomenon has been described as the "boomerang effect." See $\mathrm{H}$. Denenberg, R. Eilers, G. Hoffman, C. Kinne, J. Melone \& H. Snider, Risk AND INSURANCE 62 (1964).

214 See L. Festinger, A Theory of Cognitive Dissonance (1957).

21s "The notion of risk is an extraordinarily constructed idea, essentially decontextualized and desocialized. Thinking about how to choose between risks, subjective values must have priority. It is a travesty of rational thought to pretend that it is best to take value-free decisions in matters of life and death." $M$. Douglas \& A. WildavSKy, Risk and Culture: AN EsSay on the Selection of Technical and ENviRONMENTAL DaNGers 73 (1982).

216 See supra notes 219-228 and accompanying text.

${ }^{217}$ See W. Rowe, supra note 204, at 152. 
number of individuals involved and the injuries suffered, cannot assume an equivalence between $x$ deaths, in separate unrelated episodes, spread over time, and $x$ deaths occuring roughly coincidentally as the result of a single accident or catastrophe. Ten deaths from separate auto accidents may not be as onerous as ten deaths from a single traffic pileup during a storm. And the larger the numbers, the greater the disparity between the episodic injuries and the catastrophic injuries. ${ }^{\mathbf{2 1 8}}$ Catastrophic events may have effects beyond the sum of individual injuries for several reasons. Social disruption may result if the damage exceeds the limits of disaster relief organizations and loss-spreading insurance, and if health care organizations are unable to deal with catastrophic health problems. Psychological harm, including fear of future death or illness due to long-term effects, may result. A catastrophic event, therefore, cannot be expressed in terms of the number of deaths and injuries it produces. Second, irreversible negative results cannot be rationally discounted by their probability: permanent harm extends infinitely and is thus immeasurable for purposes of risk analysis. ${ }^{219}$ Second, individuals may be risk averse with regard to sufficiently high losses, even though the probability of occurrence is slight, for psychological reasons. Full elimination of a hazard is often valued more highly than protection based on probability, even if their utility is the same. ${ }^{220}$ Explanations for such risk-averse behavior range from historical ${ }^{221}$ (past accidents have sensitized us to the hazards of activities previously

218 Analysts have suggested a weighting factor to accommodate the greater impact of $x$ lives lost at one time compared to the impact of one life lost in each of $x$ separate incidents. See Slovic, Fischhoff \& Lichtenstein, supra note 197, at 208.

219 See W. Rowe, supra note 204, at 132.

230 [A] protective action which reduces the probability of a harm from 1 percent to zero, say, will be valued more highly than an action that reduces the probability of the same harm from 2 percent to 1 percent. Indeed, probabilistic insurance, which reduces the probability of loss by half, is judged to be worth less than half the price of regular insurance that eliminates the risk altogether.

Twersky \& Kahneman, The Framing of Decisions and the Psychology of Choice, 211 ScI. 453 (1981).

In economic behavior, hedging, cost-plus contracts, and insurance illustrate behavior which is inconsistent with risk-neutrality. Such risk-averse behavior leads to higher precautionary burdens on individuals and social resources than would be suggested by a straightforward application of a risk-benefit calculus. "The fact is, most people are willing to pay excessive amounts of money to get rid of vagueness. Perhaps this is because they don't know how to cope with it rationally or purposively or perhaps the explanation is more purely emotional, the specific reasons are immaterial." H. RAIFFA, Decision ANALYsis: InTRODUCTORY LeCTURES ON CHOICES UNDER UNCERTAINTY 159 (1968).

231 See generally W. Rowe, supra note 204, at 263-64 (describing the increased awareness of the side effects and potential irreversible harm of new technological systems, such as liquified natural gas tankers and nuclear power plants). 
unsuspected), biological ${ }^{222}$ (there may be an evolutionary advantage to special concern about catastrophic accidents), and cultural (the public perception of risk is a collective construct, produced by the selective focus of our social organizations on certain dangers). ${ }^{223}$ Whatever the causal explanation, individual risk-aversion to catastrophic results, beyond what a utility analysis would predict, is part of the mental frame of individuals.

\section{The Value of a Judicial Response}

Development of a concept of nuisance entitlements based upon a consequence-oriented risk assessment can thus be justified by reference to the traditional response of courts to social risks and the problems potential catastrophe poses for risk analysis-the expanded impact of catastrophic events, the difficulty of discounting irreversible catastrophes, and the psychological fact that people are risk averse with regard to catastrophic losses. The concept of dread, as developed in the older nuisance cases and by Nozick, captures some of the underpinnings of this consequence-oriented viewpoint. A pattern of consequence-oriented regulation has emerged in recent federal legislation, ${ }^{224}$ and in judicial review of this legislation. Statutes governing public suits for abatement of nuisances typically authorize injunctive relief upon a showing of "imminent and substantial endangerment to health or the environment, ${ }^{3228}$ a standard which has been liberally construed. ${ }^{226}$ The focus

222 See Mole, Accepting Risks for Other People, 69 Procendings of the Royal SOCIETY OF MEDICINE 107, 109 (1976) ("special concern about a simultaneously occuring group of casualties may possibly be determined not only by social conventions but also by a basic human characteristic with evolutionary advantages and therefore not eradicable by reason and information"). For a discussion of the impact of evolutionary behavior on law, see Hirshleifer, Privacy: Its Origin, Function, and Future, 9 J. LEG. STUD. 649 (1980).

${ }^{223}$ M. Douglas \& A. Wildavsky, supra note 215, at 186.

224 See, e.g., Clean Air Act, 42 U.S.C. $\$ \S 7401-7642$ (Supp. IV 1980); Federal Water Pollution Control Act, 33 U.S.C. $\$ \$ 1251-1376$ (Supp. III 1979); Safe Drinking Water Act, 42 U.S.C. $\$ \S 201,300 f-j$ (Supp. IV 1980); Federal Insecticide, Fungicide and Rodenticide Act, 7 U.S.C. \$§ 135-136 (1976); Occupational Safety and Health Act of 1970,29 U.S.C. $\$ \S 651-678$ (1976).

${ }_{225}$ E.g., Water Pollution Control Act, 33 U.S.C. \$ 1364(b)(1); see also Resource Conservation and Recovery Act, 42 U.S.C. $\$ \S 6901-6987$ (1976), which further authorizes the EPA administrator to seek a federal injunction restraining improper "handling, storage, treatment, transportation, or disposal" of hazardous wastes. Id. § 6973.

${ }_{228}$ See Reserve Mining Co. v. EPA, 514 F.2d 492, 529 (8th Cir. 1975) (en banc), in which the Federal Water Pollution Control Act's standard of "endangering the health or welfare of persons," 33 U.S.C. $\S 1160(\mathrm{~g})(1)(1976)$ was held to include potential as well as actual harm.

In assessing probabilities in this case, it cannot be said that the probability of harm is more likely than not. Moreover the level of probability does not 
has been on the severity of the hazard rather than the probability of harm, in areas of scientific uncertainty and potentially devastating consequences. ${ }^{227}$ Nuisance law, as a common law source of entitlements for private parties, can be redirected to adopt this approach. Judicial decisionmaking requires a reasoning process that gives weight to appropriate factors. If the judicial framework is oriented toward a probabilityweighted calculus, ignoring high gravity results if the probabilities seem low enough, ${ }^{228}$ the consequences, even if potentially catastrophic, will be experienced as trivial, to be ignored by a "rational" decisionmaker. But if the judicial framework for nuisance law is oriented toward consequences, considering catastrophic impacts as a central concern, then public actions derived from private entitlements will be brought into line with modern legislation and contemporary concerns about potential irreversible catastrophe.

Nuisance law can supply us with a judicial framework which provides a broader perspective on risks, drawing on the ability of a judicial decision, by elaborating on a norm or right, to educate us about the social impact of an activity. Judicial intervention may change our habits of thought in the face of an uncertain hazard by enhancing the imaginability of the consequences, and illustrating the sequence of steps

readily convert into a prediction of consequences. . . . The best that can be said is that the existence of this asbestos contaminant in air and water gives rise to a reasonable medical concern for the public health. The public's exposure to asbestos fibers in air and water creates some health risk.

514 F.2d at 520. See also Ethyl Corp. v. EPA, 541 F.2d 1, 13 (D.C. Gir.) (en banc) ("endanger means something less than actual harm"), cert. denied, 426 U.S. 941 (1976); Envt'l Defense Fund, Inc. v. Ruckelshaus, 439 F.2d 584, 597 (D.C. Cir. 1971) ("a hazard may be 'imminent' even if its impact will not be apparent for many years").

${ }_{227}$ In Ethyl Corp. v. EPA, 541 F.2d 1 (D.C. Cir.) (en banc), cert. denied, 426 U.S. 941 (1976), the court considered the public health hazards of leaded gasoline: "[T]he public health may properly be found endangered both by a lesser risk of a greater harm and by a greater risk of a lesser harm. Danger depends upon the relation between the risk and harm presented by each case." 541 F.2d at 18 (footnotes omitted). In United States v. Vertac Chemical Corp., 489 F. Supp. 870 (E.D. Ark. 1980), the government sought an injunction ordering a chemical corporation to commence abatement proceedings against dioxin: "While there may be a low probability of harm from dioxin as defendants contend, there is a serious and dire risk from exposure to dioxin should the hypothesis advanced by the plaintiffs prove to be valid." 489 F. Supp. at 885. The court quoted Judge Skelly Wright's dissent in Ethyl Corp. v. EPA, No. 732205, slip op. at 11, (D.C. Cir. Jan. 28, 1975) (Wright, J., dissenting), rev'd, 541 F.2d 1 (D.C. Cir.) (en banc), cert. denied, 426 U.S. 941 (1976): " "A risk may be assessed] from suspected, but not completely substantiated, relationships between facts, from trends among facts, from theoretical projections from imperfect data, or from probative preliminary data not yet certifiable as "fact." " 489 F. Supp. at 885 .

${ }^{228}$ The Nuclear Regulatory Commission's regulations are probability-oriented, going so far as to preclude consideration of catastrophic accidents in the course of licensing proceedings. See Green, Public Participation in Nuclear Power Plant Licensing: The Great Delusion, 15 WM. \& MARY L. Rev. 503, 514-15 (1974). 
that might cause the actualization of the consequences. The discussion of possible risks, their likelihood, and alternative pathways open up the technology to a range of considerations that might not otherwise have been apparent.

\section{Public Action and Private Law}

A litigation model based upon the re-emergence of the equitable powers of the judiciary may have advantages in coping with risks involving catastrophic consequences. The model is patterned after the "public law" litigation model, in which the courts have entered the spotlight "as part of a gathering effort to control the bureaucracies of a complex modern society." ${ }^{229}$ In these cases the judge, exercising equitable powers, fashions an ongoing decree at the end of a complex litigation process, including elements of negotiation and mediation, among a range of affected parties. The procedural arsenal used by judges in these cases has long been available. The courts are seeking to protect new entitlements through an expanded use of traditional equitable powers and an enlarged concept of judicial oversight. ${ }^{230}$

\section{A. The Public Action Model}

A judicial risk-assessment suit, brought to initiate inquiry into the hazards of a scientific or technological activity, would constitute a "public action." This term, which is roughly synonomous with "public law litigation"231 and "complex enforcement,"232 describes a wide range of suits that share the characteristic of affecting a large number of persons through the resolution of a significant issue of public policy. ${ }^{233}$ The observations of Abram Chayes on this area of litigation illustrate the appropriateness of a public action for the resolution of disputes over scientific research:

The interest of absentees . . . becomes more pressing as so-

229 Chayes, Foreword: Public Law Litigation and the Burger Court, 96 Harv. L. REv. 4, 60 (1982).

230 See Eisenberg \& Yeazell, The Ordinary and the Extra-ordinary in Institutional Litigation, 93 HARv. L. REv. 465 (1980).

${ }^{231}$ Cogan, Some Thoughts on the Meaning of "Public Action" and the Concerns of Public Action Adjudication, 13 U.C.D. L. Rev. 215, 216 (1980).

${ }^{232}$ See Note, Complex Enforcement: Unconstitutional Prison Conditions, 94 HaRv. L. REv. 626, 626 n.1 (1981).

2ss For discussions of the reasons why such suits should be and have been permitted despite the apparent absence of traditional standing prerequisites, see J. VINING, supra note 161, and Jaffe, The Citizen as Litigant in Public Actions: The NonHohfeldian or Ideological Plaintiff, 116 U. PA. L. REv. 1033 (1968). See also Justice Blackmun's dissenting opinion in Sierra Club v. Morton, 405 U.S. 727, 759 (1971). 
cial and economic activity is increasingly organized through large aggregates of people. An order nominally addressed to an individual litigant-the labor injunction is an early example-has obvious and visible impact on persons not individually before the court. . . . In cases of this kind, the fundamental concept of litigation as a mechanism for private dispute settlement is no longer viable. The argument is about whether or how a government policy or program shall be carried out. $^{234}$

The common law of public and private nuisance shares many characteristics with the modern public action. Unlike damage actions, which involve reconstruction of a past set of events, nuisance actions, like public actions, are brought to influence future events. ${ }^{295}$ The relief afforded must protect the rights of interested parties who may not be before the court. ${ }^{238}$ The fact-finding function of the judge in both nuisance and public actions differs from the traditional damage model, since it is prospective, requiring assessment of alternative plans to correct the problem. The process looks more and more "legislative" as the traditional adversarial structure breaks down. The judge accumulates responsibility for factfinding, as he "is placed in an active role in shaping, organizing and facilitating the litigation."2sz

As is the case with modern public actions, a risk-assessment action based on nuisance would entail a negotiation process culminating in a decree. The negotiation process mitigates objections based on the intrusiveness of complex decrees. ${ }^{238}$ Where judges have felt a need to gener-

2s4 Chayes, The Role of the Judge in Public Law Litigation, 89 Harv. L. REv. 1281,1294 (1976). See also Chayes, supra note 229, at 56, in which Chayes updates his conception of public law litigation:

I began this essay by posing the question whether public law litigation, seemingly an expression of a liberal and reformist ideology in the legal system, would be able to withstand prolonged confrontation with a Supreme Court whose dominant tenor was neither liberal nor reformist. I submit that the foregoing reconnaissance, limited and fragmentary as it is, provides considerable evidence that the attributes of public law litigation are strongly resistant to conscious efforts at reversal.

2ss See Chayes, supra note 234, at 1293.

238 Sep id. at 1292.

237 See id. at 1297; see also K. Davis, Administrative Law Treatise $\$ 12.3$ (1978) (distinguishing between "legislative" and "adjudicative" facts).

${ }^{238}$ See Chayes, supra note 234 , at 1299 . For a favorable discussion of decisionmaking through negotiation and adjudication, see Eisenberg, Private Ordering Through Negotiation: Dispute-Settlement and Rulemaking, 89 HARv. L. REv. 637, 654 (1976). See also Fuller, The Forms and Limits of Adjudication, 92 Harv. L. Rev. 353,371 (1978) (defining certain areas of human association in which adjudication is an inappropriate form of social ordering). 
ate information and develop proposals, they have often appointed masters, amici, panels, and advisory committees. ${ }^{239}$ The breadth of interests represented raises questions about the adequacy of the representation afforded by a single plaintiff. The potential of the judicial system to respond to interests that may not be adequately represented in a legislative setting or in the context of agency action is substantial. In any proceeding with broad public impact, whether judicial or administrative, we do not have a reliable way to identify the affected interests. However, the courts may be in a better position than the legislature to respond to those interests. The judge is insulated from the risk of being "captured." $240 \mathrm{He}$ can require notification and draw in outside viewpoints. He also has the power to appoint a guardian ad litem for unrepresented interests, or an ombudsman. ${ }^{241}$

The flexibility of injunctive relief in public actions makes it a particularly appropriate means of controlling hazardous activities before the full extent of the risk is fully known. An injunction seeks to prevent a future wrong, conditioned on a showing that there is a probability (of some indeterminate magnitude) of that future wrong's occurrence. It has traditionally been seen as a supplement to the compensatory system, invoked only where damages are for various reasons unsatisfactory. The threat of a permanent injunction compels bargaining and facilitates it. Such an injunction may be a preferred remedy where no damage has occurred, but a high-risk activity is being conducted, thus inducing in plaintiffs a dread of harm. The preventative injunction overlaps both the regulatory and the structural injunction, as the older injunction cases illustrate. Thus the bargaining process may involve mediation by the judge and in some instances an ongoing regulatory decree. $^{242}$ The ongoing decree has been common in nuisance cases where an absolute injunction or a flat denial is inadequate. In some

239 See Chayes, supra note 234, at 1301 and cases cited at 1301 n.87.

${ }^{240} I d$. at 1310. See Stewart, The Reformation of American Administrative Law, 88 HaRv. L. REv. 1667, 1684-88 (1975).

241 Parties who are potentially affected may be fearful of judicial procedures or may lack the resources necessary to pursue their interests. Notions of due process may therefore require flexibility in "looking beyond the traditional adversary model for procedures to restrain arbitrary governmental action." L. TRIBE, AMERICAN CONSTITUTIONAL LAW, § 10-19 (1978).

242 See Chayes, supra note 234 at 1292-94. Decrees that impose conditions upon the continuation of an activity can be found in a number of nuisance cases. See, e.g., Renken v. Harvey Aluminum, Inc. 226 F. Supp. 169 (D. Ore. 1963) (aluminum reduction plant required, inter alia, to install cell hoods preventing excessive emission of flourine); Stevens v. Rockport Granite Co., 216 Mass. 486, 104 N.E. 371 (1914) (general injunction not to commit nuisance, with caveat that defendant could install devices to block escape of dust); Collins v. Wayne Iron Works, $227 \mathrm{~Pa}$. 326, 76 A. 4 (1910) (imposing conditions on operation of noisy iron works). 
such cases, the court has directed the defendant to experiment with means of reducing the hazard, providing for periodic reports back to the court or a special master. ${ }^{243}$

\section{B. The Strengths of the Public Action Nuisance Model}

Critics have called nuisance doctrine anachronistic, ${ }^{244}$ designed as a means of resolving neighborly disputes about trivial annoyances, rather than for the uses which modern advocates propose. Is the attempt to build upon nuisance law simply a lawyer's trick, an appropriation of a distinct concept without acknowledging a change in meaning? ${ }^{245}$ Nuisance law has a clear substrata of caselaw which considered dread of catastrophic results a proper basis for injunctive relief. By eliminating the more modern process of balancing the harm against the utility of an activity at the threshold level of definition, we can return nuisance law to its historical beginnings as a device for technology control. However, it is not doctrine which troubles modern critics. Arguments against such a nuisance action center on the capacity of the judiciary. Relative institutional ability provides the focal point for such criticism, which attempts to lay down theoretical limitations on the ability of courts to deal with complex modern hazards.

Critics make the following arguments:

(1) episodic lawsuits cannot provide for broad policy considerations, as can a national regulatory body, nor can they fit an individual case into an integrated plan; ${ }^{248}$

(2) lawsuits are usually brought too late, because of the necessity of proving damage as a basis for recovery, to prevent problems of environmental degradation or damage to public health from the release of such harmful instrumentalities as

243 For a series of cases in which the court in effect set emission standards in advance of the existence of regulatory agencies like the EPA, see Georgia v. Tennessee Copper Co., 206 U.S. 230 (1907); 237 U.S. 474 (1915); 240 U.S. 650 (1916) (abating nuisance from smelting of copper, a limited injunction was issued, based upon the reports of a court-appointed inspector).

The Restatement (SECOND) of ToRTs, § 941 comment e (1977), acknowledges that "much can often be accomplished by an order requiring experiments to be conducted under neutral scientific supervision. ... . In appropriate cases, experiments should be undertaken before an injunction against nuisance or stream pollution is denied on the ground of relative hardship or of countervailing public interest."

${ }_{244}$ See, e.g., Pfennigstorf, Environment, Damages, and Compensation, 1979 AM. B. Found. Res. J. 349, 356.

${ }^{215}$ See Posner, Lawyers as Philosophers: Ackernan and Others, 1981 AM. B. Found. REs. J. 231, 249.

246 See generally Developinents in the Law-Zoning, 91 HaRv. L. REv. 1427, 1584 (1978). 
toxic chemicals; ${ }^{247}$

(3) the costs of judicial supervision are excessive, ${ }^{248}$ and in the area of complex technological hazards, supervision may be beyond the sophistication of the courts; ${ }^{249}$

(4) prospective lawsuits for relief, even if adequate doctrinal underpinnings were available, are too dependent upon the willingness and financial ability of private groups to sue, leading to spotty, incomplete regulation.

The public action nuisance model can withstand the criticisms directed at reform of nuisance doctrine as a means of supplanting public regulation. Where the feared activity, such as scientific research in new areas, is carried out intentionally in an environment of social optimism toward research and its fruits, the tort process, initiated and conducted by the interested injured party, is a public action, substituting for government regulation. It is a form of institutional skepticism, a check on the momentum of activities whose effects are not yet clearly apparent. A court is the ideal institution to change incrementally to deal with putative hazard, obviating the necessity for a new social mechanism, while providing a rich tradition suited for the problem.

First, a court may have advantages in gathering and assessing information. ${ }^{250}$ Parties will have a strong incentive to present information, and if the party structure is adequate, much information should be produced. This can be subjected not only to adversarial review, but also to the review of experts appointed by the judge to evaluate complex scientific issues. ${ }^{251}$ It has been argued that in certain contexts the parties to litigation may lack a real interest in helping the court under-

247 See Note, Allocating the Costs of Hazardous Waste Disposal, 94 Harv. L. REv. 584, 589-90 (1981).

248 See generally D. Horowitz, The Courts and Social Policy (1977).

249 See Bereano, Courts as Institutions for Assessing Technology (paper presented at 1972 Annual Meeting of the American Association of Atomic Scientists) quoted in D. HoRowrTz, supra note 248, at 39 (courts are "poorly equipped to perform early warning functions since there are not motivated parties to clearly present the issue" before harm occurs); see also Yellin, supra note 4 (proposing review board composed of masters trained in law and science).

${ }^{250}$ See Chayes, supra note 234, at 1308; Wellington, Common Law Rules and Constitutional Double Standards: Some Notes on Adjudication, 83 YAlE L.J. 221, 240-41, 248-49 (1973). The adversary model has often been seen as an effective framework for resolving complex issues, a process in which such complexities are "resolved in the crucible of debate through the clash of informed but opposing scientific and technological viewpoints." Int'l Harvester Co. v. Ruckelshaus, 478 F.2d 615, 652 (D.C. Cir. 1973) (Bazelon, C.J., concurring) (challenge to EPA ruling on automobile emissions). See also Miller \& Barron, The Supreme Court, the Adversary System, and the Flow of Information to the Justices: A Preliminary Inquiry, 61 VA. L. REv. 1187 (1975).

${ }^{251}$ See Chayes, supra note 234 at 1308. 
stand the technical and scientific complexities of an issue, or that certain information will not be developed for tactical or other reasons. ${ }^{252}$ In the nuclear energy context, it has been argued that the benefits of the adversary process in reviewing agency decisionmaking has come at the cost of detracting from the substantive quality of the decisions, because of the complex hybrid technological-legal questions posed. ${ }^{253}$ The answer is to amend the adversary model, as the public action cases demonstrate, ${ }^{254}$ to enhance sources of information and judgment, especially if the interests of the parties are not sufficient to generate all of the relevant information.

The argument that the litigation process can neither improve the scientific underpinnings nor the reasoning process involved in complex agency regulation of technological risks must also be dealt with at the "first look" level. For if a court lacks as a fundamental characteristic the ability to generate and evaluate complex scientific evidence, then the deficiency will pervade its evaluations both at the level of agency review and at the level of "first look" decisionmaking in private or public litigation. What evidence is there of such judicial shortcomings? The primary argument is based upon the history and nature of the adversary system. In the words of one critic:

stripped of its modern instrumental trappings, the adversarial engine sets the stage for explicit justice, and on that stage factual findings are mainly made by exploring human sense perceptions. Complex environmental findings do not lend themselves to such direct observation, and adversarial devices do not improve their reliability or evidentiary value. $^{250}$

The adversarial devices-cross-examination of witnesses, ${ }^{258}$ evidentiary rules which focus on testimonial infirmities, and procedural rules for the discovery of information-from this perspective, are aimed primarily at evaluating witness perception of phenomena and events

${ }^{252}$ See Yellin, supra note 4, at 508, 529-31 \& 552-53 (1981).

${ }^{253}$ Id. at 508.

254 See supra notes 202-40 and accompanying text.

265 Yellin, supra note 4, at 549. Yellin has made this point in an earlier article. See Yellin, Judicial Review and Nuclear Power: Assessing the Risks of Environmental Catastrophe, 45 Geo. WASH. L. REv. 969, 981 (1977).

${ }^{258}$ See FED. R. EvID. 611. Wigmore may have overstated the case in describing cross-examination as the "greatest legal engine ever invented for the discovery of truth," but courts have consistently acknowledged its importance and its constitutional underpinnings. See United States v. Segal, 534 F.2d 578, 582 (3d Cir. 1976) ("the right of cross-examination is of constitutional dimension and may not be denied"). 
accessible to the unassisted senses. ${ }^{287}$ This takes too narrow a view of the evidentiary materials that have traditionally been admissible in litigation, ignoring the need to reconstruct complex past events by reference to analogy, past history, and statistical patterns. ${ }^{258}$ In evaluating past events, for example, we have drawn upon scientific testing as an aid to reconstructing events where eyewitnesses are lacking. ${ }^{259}$ The common law nuisance and trespass cases dealt with harms normally detectable by the unaided senses because those were the only harms recognized prior to the development of more sophisticated means of enhancing our senses. But this suggests the existence of a need for increased sophistication on the part of both judges and lawyers to handle the newer technologies of detection and analysis, rather than an inherent limitation of the judiciary.

Cross-examination can aid in assessing expert judgments. It can serve as a probe of forecasts and general conclusions underlying future planning issues, just as effectively as it serves to evaluate past events. ${ }^{280}$ Underlying biases, unstated assumptions, and methodological shortcomings can be easily revealed by an effective cross-examination.

Moreover, a legal complaint phrases a grievance in a way that a defendant cannot ignore. ${ }^{261}$ The defendant must respond at each stage or risk penalties such as dismissal or even contempt citation. Because a court must respond to a complaint, litigation is more potent than either an agency or a legislature in following through on grievances.

A judicial first-look mechanism can send a message to government decisionmakers, particularly Congress, when the risks under consideration are unrecognized, unregulated or underregulated. Judicial ability to affect government action, either at the first or second look level, requires an ability to consider technical issues systematically, in order to convey their analyses and conclusions to professionals in the govern-

257 The claim is that the common law causes of action, such as trespass and nuisance, were designed to deal with harmful effects that may be detected by the "unassisted senses," see Missouri v. Illinois, 200 U.S. 496, 520 (1906), rather than with the subtle injuries caused by microorganisms, chemicals and radiation.

258 The Federal Rules of Evidence, for example, provide for a limited use of character evidence to prove conduct, provide for proof of character, and permit evidence of habit to prove conduct on a particular occasion. FED. R. EvID. 404, 405, 406. Courts in older cases have relied on recurring patterns to establish causation. See, e.g., Stubbs v. City of Rochester, 226 N.Y. 516, 124 N.E. 137 (1919) (statistical evidence adduced to establish causation between contaminated water supplies and typhoid fever infections).

${ }^{238}$ See generally Moenssons \& InBAU, ScIEnTIFIC EvidenCE IN CRIMINAL CAses (2d ed. 1978).

${ }^{280}$ Robinson, The Making of Administrative Policy: Another Look at Rulemaking and Adjudication and Administrative Procedure Reform, 118 U. PA. L. REv. 485, 521-22 (1970).

261 See Diver, supra note 242, at 66. 
ment and in agencies, transmitting a sense of the heft of the case and the weight of opposing arguments. ${ }^{262}$ Where Congress has considered regulating in an area of scientific controversy, a judicial decision and a decree incorporating various structural constraints would convey-more sharply than a string of witnesses in a Congressional hearing-the urgency of a problem, a reasoned analysis of the risks, and the outlines of a framework for further regulation. Judges are trained in the analysis of problems, with the ability to suspend judgment initially until the parties have hammered out areas of disagreement and agreement. ${ }^{263}$ They are free of political pressures, unlike Congress and federal agencies, and thus better able to take a position and mandate changes. In public actions involving the administration of institutions such as school systems and prisons, it may be that the task of ongoing management strains the limits of judicial management to its utmost, impairing in some cases the day-to-day operation of the system. ${ }^{264}$ However, the assessment of new hazards is a more familiar task, albeit one complicated by scientific uncertainty. Courts have traditionally evaluated alternative means of reducing risks or provided incentives for the parties to do so. Finally, a high degree of participation by affected parties can be achieved through the appointment of amici and other representatives of groups who would not otherwise be heard in the setting of agency rulemaking or Congressional legislation. ${ }^{265}$

The decentralized character of litigation has drawbacks as well as

${ }^{262}$ See Leventhal, Environmental Decisionmaking and the Role of the Courts, 122 U. PA. L. REv. 509, 525, 536 (1974); see also Bazelon, Implementing the Right to Treatment, 36 U. CHI. L. REv. 742,749 (1969) ("courts fulfill a necessary function when the drama and publicity attending a concrete case provide the illumination of dark recesses which is essential if society and its legislatures are to make informed judgments"). (1977).

${ }^{263}$ See Oakes, The Judicial Role in Environinental Law, 52 N.Y.U. L. REv. 498

${ }^{264}$ See the extended critique in D. Horowrrz, supra note 248, at 264, describing:

the impotence of the courts to supervise the implementation of their decrees, their impatience with protracted litigation, and their limited ability to monitor the consequences of their action. Called upon increasingly to perform administrative functions because they are not burdened with administrative rigidities, the courts are also not blessed with administrative capabilities.

For an interesting first-person account, see Wood, Managing a School System Under Court Order, Wall St. J., Mar. 30, 1981, at 22, col. 3: "What was most frustrating to an administrator . . . was that the logic of court procedures makes it exceedingly difficult for me and my colleagues to make orderly, timely or rational management decisions."

${ }^{265}$ Stewart has described the expansion of the right of intervention both in agency decisionmaking and in appeals from agency decision, in Stewart, supra note 240 , at 1748-52. 
advantages, however. While bargaining may be facilitated, a would-be victim must be found, willing to undertake the litigation, as well as a lawyer who can be assured payment. This suggests the need for some sort of public fund to compensate attorneys for public law litigation where no damages are alleged and no statute invoked, and where the end result of litigation may not be a win-or-lose decision, but rather an ongoing decree or simply a complete factual record available for public scrutiny and information. ${ }^{268}$

\section{The Nuisance Action Revived: The "First Look Doctrine"}

Nuisance law can be provided with a more flexible framework for resolving disputes in areas of scientific uncertainty. Courts have for too long merged the issues of the existence of nuisance with the question of the remedy sought, denying the existence of a nuisance when the prohibitory injunction seemed too harsh a remedy. Thus, a cost-benefit calculation is usually made at the level of determining whether a nuisance exists, balancing conflicting interests and the usefulness of the risky activity. Even if a nuisance is found, the court will again balance interests on the issue of granting the injunction against the nuisance. ${ }^{267}$ This process, which leads to the dismissal of actions against otherwise actionable nuisances because of judicial reluctance to grant permanent injunctions, fails to take into account the very flexibility inherent in the equitable powers of the judiciary. The proposed solution is a three step analysis, ${ }^{288}$ closer to that which originally characterized nuisance litigation: first, a judicial determination of the substantive issue of the existence of a nuisance; second, the generation of information about the hazards and their alleviations, through allocation of the burdens of proof to those parties best equipped to produce information; third, judicial monitoring to aid the parties in negotiating a decree.

\section{The Prima Facie Case}

The prima facie case for a hazardous activity requires evidence of

${ }^{268}$ See Note, Awards of Attorneys' Fees to Unsuccessful Environmental Litigants, 96 HARV. L. REv. 677, 677 \& n.3 (1983), for a list of federal environmental statutes authorizing fee awards whenever the court finds such an award "appropriate."

267 See Restatement (SECOND) OF TORTS, § 941, comment c (1977).

26s I am indebted to Joel Yellin, whose article, supra note 255 , oriented my thinking in the directions which $I$ have developed. His discussion, particularly at 985-88, contains a number of suggestions which I have expanded and fleshed out. See also Rabin, Nuisance Law; Rethinking Fundamental Assumptions, 63 VA. L. Rev. 1299, 1300 (1977) (describing an analogous, two-step approach). 
endangerment. ${ }^{269}$ Endangerment details an assertion of possible harm which at a minimum does not violate any known scientific principle, which cannot be disproved on the basis of current scientific knowledge, and which cannot be eliminated on the basis of current information. Plaintiff must establish that a hazard exists, the consequences of which are sufficiently severe to qualify as catastrophic. ${ }^{270}$ The plaintiff's special damages would be the dread which is the logical effect of a hazardous activity whose effects cannot currently be prevented. A judicial decision would thus include evaluation of the physical possibility of the feared outcomes, based on prior historical experience, experimentation, or knowledge of the physical laws involved, ${ }^{271}$ and the kind of harm to public health or the environment which will result if the feared harm materializes. The prima facie case establishes the plaintiff's right not necessarily to injunctive relief, but to more information. ${ }^{272}$

\section{The Generation of Information and Reduction of Uncertainty}

The finding of a prima facie nuisance would effect a judicial presumption that the risky activity needs better controls than we trust at present either self-regulation by those involved, or the workings of the market, to provide. Technology assessment is the goal of step two, which is interconnected with and proceeds simultaneously with the negotiation process of step three. New information about the nature of the hazard and the probabilities of its occurrence is sought, as the parties further identify and estimate the risks. The burden of producing evidence is on that party in the best position either to produce it or to generate new information through testing and other means. Such information would include: an account of the reliability of available information; possible alternatives to the proposed activity; ${ }^{273}$ the social con-

${ }^{280}$ See supra note 224 for statutory references to "endangerment".

${ }^{270}$ See Yellin, supra note 255, at 987-88, for a discussion of such an approach to nuclear power regulation.

271 See, e.g., Bethe, Ultimate Catastrophe?, Bulu. Aтом. Sar., June, 1976, at 36 (discussing impossibility of ignition of ocean or atmosphere by nuclear explosion).

${ }^{272}$ This step must take note of the limitations of relying on decentralized, individual-initiated litigation. First, one needs information that risks are being created, since most hazards of scientific research are not visible to the senses and are therefore speculative. The willingness of individual scientists to come forward with concerns, coupled with legal protection for whistle-blowers against retribution by employers, may be the only way to provide the initial information. Certainly the actions of Paul Berg and others in addressing the hazards of recombinant DNA research indicates potential for such an early warning system. The idea of a relationship between the Office of Technology Assessment and academic scientists, whereby various lines of research are analyzed on a contract basis, has potential as well.

${ }^{273}$ See Noll \& Thomas, The Economic Implications of Regulation by Expertise: The Guidelines for Recombinant DNA Research, in RESEARCH WITH RECOMBINANT 
text of the activity - the relative ability of the parties to the immediate lawsuit to bargain and the need to join other affected interests; and the limits that can be set on the feared outcome, based upon current knowledge, such as experience in dealing with epidemics through public health controls. ${ }^{274}$

\section{The Negotiated Decree}

The third step develops the remedy, in a process by which the judge draws upon his equitable powers. A finding of a prima facie nuisance having been made, the parties can now negotiate with the help of the judge, as they should have in the first place. Ventilation of the issues occurs in an environment in which the presumption is against continuation of the activity in its present form. A nuisance has been found, as a threshold matter-an activity creating a high-consequence risk, one whose probabilities of actualization are unknown, generating dread in those who are either in proximity to the activity or within the casual line of sight of the dreaded harm. The remedy stage of the revised nuisance model for complex hazards is a form of judicial rulemaking by negotiation. ${ }^{275}$ Several advantages accrue from the flexible nature of the remedy stage. In devising safeguards based upon information produced, a complex set of polycentric concerns are involved, ${ }^{278}$ which it is unlikely that a traditional adversary setting could unravel. The act of bringing multiple parties together in a negotiation model provides for an interaction of concerns. Negotiation, in the setting in which the parties are forced together (by a preliminary judicial acknowledgement, in stage one, that the activity is a nuisance) fosters a pragmatic search for options. The posturing which the adversary system sometimes encourages within the bipolar framework is likely to break down here in a common search for solutions.

Finally, a final decree based upon the negotiation will be more acceptable to the parties, since the negotiation context encourages the working out of a compromise settlement, unlike the adversary setting, a zero-sum game with only one right answer.

DNA 262 (1977).

274 Proponents of recombinant DNA research argue that even if an organism produced as a result of the technology escaped, existing public health measures would be adequate to deal with resultant epidemics and other health problems. See FiNaL EIS, supra note 9, at 80 (excerpt from letter by Roy Curtiss to Donald Fredrickson).

${ }^{275}$ See generally Note, Rethinking Regulation: Negotiation as an Alternative to Traditional Rulemaking, 94 HaRv. L. REV. 1871 (1981).

276 See id. at 1876. 


\section{Concluston}

The expansion of private law remedies to deal with the hazards of scientific research offers an opportunity to utilize an existing institution with substantial powers, in lieu of a new bureaucracy which will not achieve the goal of technology assessment. Scientists, like other professionals, can no longer lay claim to the argument that their special knowledge deserves complete autonomy. Self-regulation, in science as in the medical and legal professions, has proved insufficient. A new judicial perspective on hazards, weighing consequence over probability and utilizing flexible decrees drawn from a rich tradition of equity jurisprudence, provides a needed mechanism for confronting new hazards and gaining control over them at an early stage in their development.

A tort suit is thus a vehicle for asserting a sense of dread in the face of uncertainty and in the absence of existing public administrative regulation. It provides an existing mechanism for asserting a risk-averse approach to new scientific and technological activities. Where the expected end-product and risks are both uncertain and diffuse, but the consequences may affect a whole way of life, a burden of justifying the activity and its risks can be put on those who seek to undertake that activity. The blending of the risk-averse strain of nuisance law and the equitable powers of the judiciary may provide a potent tool of technology assessment of new activities. The thesis of this Article is that common law nuisance entitlements can be redefined to cope with the risks of modern science and technology, then coupled with the use of complex injunctive decrees to provide a prophylactic means of governing hazard. Such a private right of action is an open, nonbureaucratic means of asserting an important public value and gaining some measure of enforcement over activities occurring in a regulatory vacuum. The courtroom may also serve as a stage for dramatizing the sense of dread attendant upon many modern risk-creating activities, putting pressure upon legislatures to fill the vacuum. The courts have limits, and it is undoubtedly correct that they "apprehend and implement only a few of the various possible conceptions of institutional purpose."27z However, private lawsuits also have compensating advantages where the alternative institutions are weak or lacking. In a time of deregulation, when the Supreme Court has restricted the possibility of deriving private rights to sue from federal legislation, the common law remains a residual source of values upon which to base public actions. The best long term solution may be a mix of public and private enforcement, but

${ }^{277}$ Stewart \& Sunstein, Public Programs and Private Rights, 95 HARv. L. REv. 1193, 1319 (1983). 
until such public regulation is available, private law can become public action. 
